\title{
WAGE POLICY AND ENDOGENOUS WAGE RIGIDITY: A REPRESENTATIVE VIEW FROM THE INSIDE
}

\begin{abstract}
We report the results from a representative survey of human resource managers in 885 Swedish firms. We estimate that during the severe recession of the 1990 s, only 1.1 percent of workers took a cut in regular nominal pay. We trace the lack of wage moderation to a combination of exogenous (primarily labor law and collective bargaining contracts) and endogenous factors. Our analysis suggests that (i) endogenous wage rigidity plays an important role in most segments of the labor market, (ii) sources of endogenous wage rigidity differ significantly between the high- and low-end of the labor market, and between large and small firms, and (iii) mechanisms of wage rigidity tend to complement each other. Some of our questions deal with issues in the economics of personnel. We report evidence that job protection tends to reinforce the stigma from long-term unemployment, and that labor market training tends to reduce the same stigma. We show that managers in small organizations have a more negative attitude towards incentive schemes based on relative rewards, and we report evidence suggesting that gender have an impact on attitudes concerning effort and motivation.
\end{abstract}

JEL classifications: E24, J30, J50, C81

Keywords: wage rigidity; survey evidence; effort models; motivation; labor law; longterm unemployment; gender and pay

Jonas Agell

Department of Economics

Stockholm University

SE-106 91 Stockholm

Sweden

JA@ne.su.se
Helge Bennmarker

IFAU

Box 513

SE-751 20 Uppsala

Sweden

Helge.Bennmarker@ifau.uu.se 


\section{Table of contents}

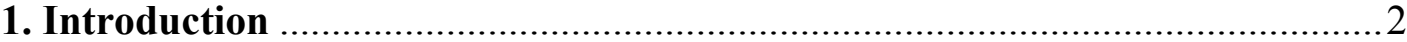

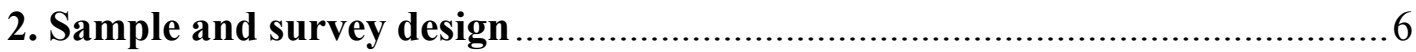

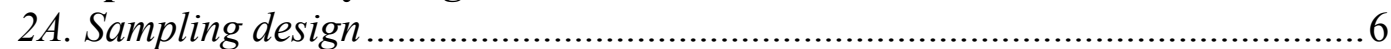

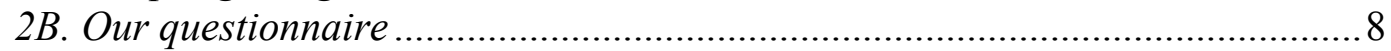

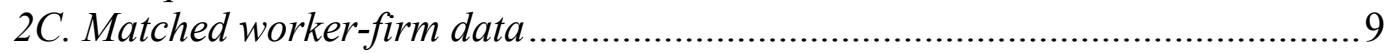

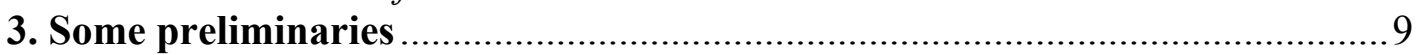

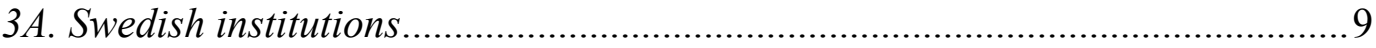

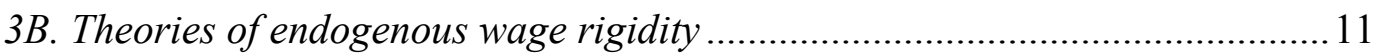

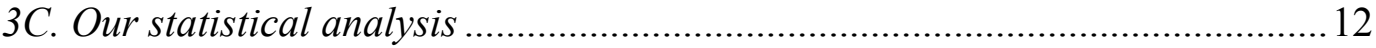

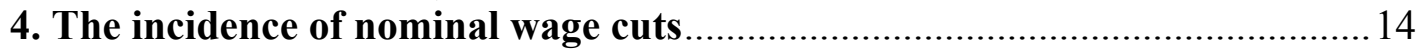

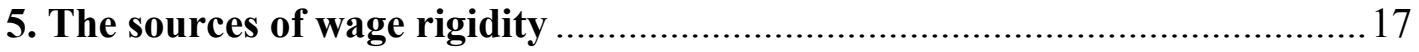

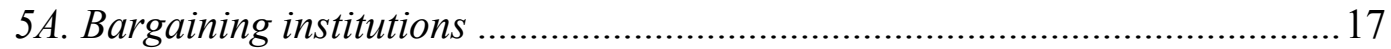

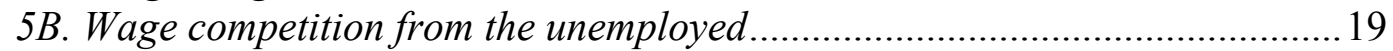

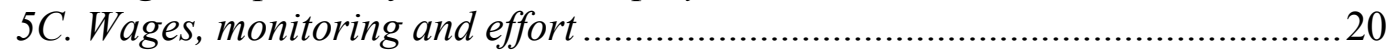

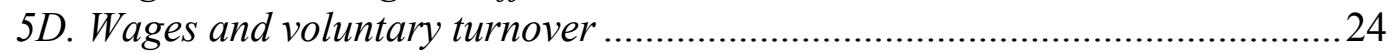

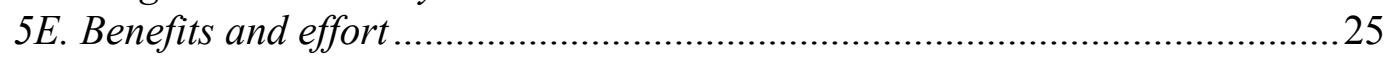

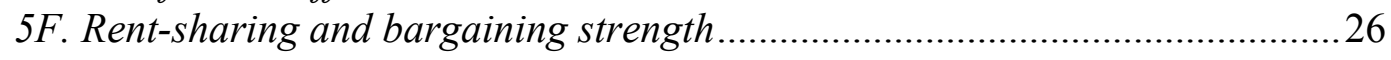

5G. Workers' wage norms and Keynes's explanation ........................................28

$5 \mathrm{H}$. On the complementarity between mechanisms of wage rigidity ......................30

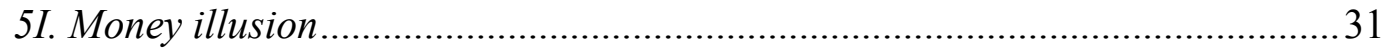

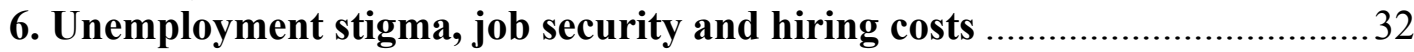

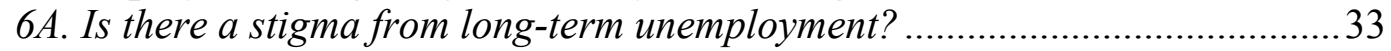

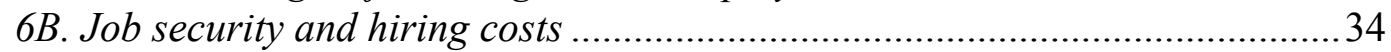

6C. Job security and the stigma from long-term unemployment ............................35

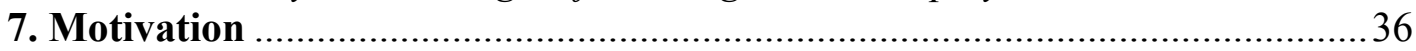

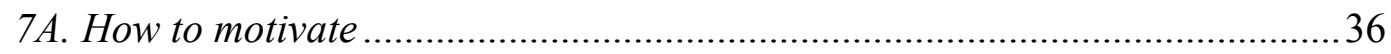

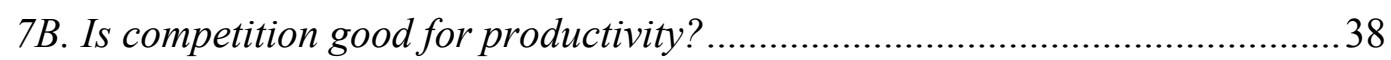

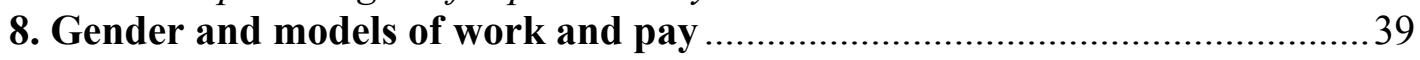

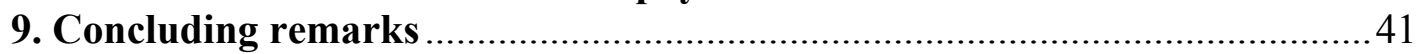

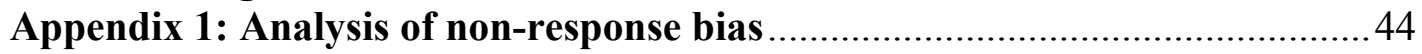

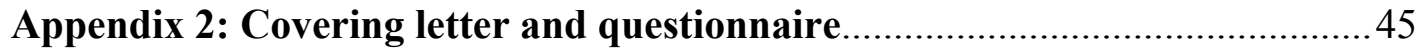

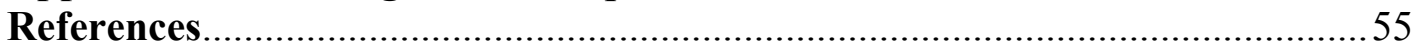

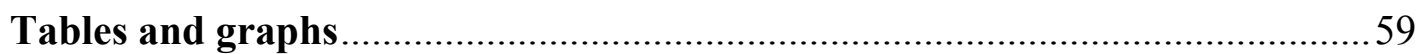




\section{Introduction}

In recent years some economists have used surveys of those who bargain over wages to understand the mechanisms of wage rigidity, see Table 1. Though this research has provided many useful insights, it falls short of the ideals proposed in sampling texts. Some studies cover very few firms; see Kaufman (1984) and Blinder and Choi (1990). Others focus on firms situated in narrowly defined business sectors, see Agell and Lundborg $(1995,2002)$. No study provides a representative coverage of small firms. Some authors obtain their samples through "snowballing", which implies that original respondents were asked for additional persons to interview; cf. the impressive study of Bewley $(1995,1999)$. Finally, due to low response rates, non-response bias is a potentially serious issue.

We improve on the statistical methodology of previous survey research. Our randomized sampling design allows us to make comparisons between segments of the labor market of particular interest for students of work and pay. Our sample was drawn to provide a balanced coverage of enterprise units in four sectors (manufacturing, unskilled services, skilled services, and public administration), and in three size categories. We took many steps to reduce non-response bias, and we obtained replies from 885 enterprise units, implying a very high response rate of 75.1 percent. Unlike previous studies we have a large sample of small firms, consisting of 300 firms with less than 20 employees. ${ }^{1}$ Moreover, Statistics Sweden provided us with extensive background information about responding units, and about their workforce.

\footnotetext{
\# Statistics Sweden was closely involved in every aspect of our project. They helped us plan the survey design, draw our random sample, suggested improvements of our questionnaire, organized the fieldwork, and took care of the electronic scoring of completed questionnaires. Finally, they gave us access to their employment and education registers. We owe a great debt to Mats Bergdahl, Agneta Sandqvist and Agneta Sträng. We also thank Steinar Holden, Erik Mellander and Henry Ohlsson, who provided detailed comments on a previous version. At an initial stage of the project we benefited from discussions with Per Lundborg. We thank Martin Agell, Erik Danhard and Jöran Tjernell for advise on the interpretation of Swedish labor law. We have benefited from seminar presentations at IFAU, Uppsala; CESifo, Munich; Finnish Labour Institute for Economic Research, Helsinki; and the 2001 Meeting of Norwegian labor economists, Bjorndalen. The project is partially financed by IFAU. ${ }^{1}$ The mean number of employees for the 19 firms interviewed by Blinder and Choi (1990) was 5767. The mean firm size in Agell and Lundborg (1995) was 1154 employees, and only a handful of their firms had less than 100 employees. Nine of the 235 businesses interviewed by Bewley (1999) had less than ten employees. The sub-sample of 73 smaller firms surveyed by Campbell and Kamlani (1997) refers to firms with less than 1000 employees that were situated in a certain geographical area, and had a connection to the authors or to Colgate University. Kaufman (1984) focuses on small firms, but his 26 firms were not drawn at random, and they were concentrated to certain geographical areas.
} 
Finally, our survey was implemented in a macroeconomic environment ideally tailored to the needs of students of wage rigidity. ${ }^{2}$ Throughout the postwar period, until 1990, Swedish unemployment never exceeded 4 percent. Between 1991 and 1993, however, GDP fell by more than five percent, and total unemployment (including those enrolled in labor market programs) increased from almost 4 percent to almost 13 percent of the work force. Between 1990 and 1994 the total number of employees decreased by 14 percent, and the rate of job destruction was high in all sectors. ${ }^{3}$ By the time we sent out our survey in early 1999 more than 10 percent of the workforce was still either unemployed, or enrolled in a labor market program. The sharp increase in unemployment brought about a rapid end to Swedish inflation. Inflation decelerated from above 10 percent in 1991, down to 2.4 percent in 1994. In the five-year period preceding our survey (1993-98) average inflation was about 1 percent, with little variation between years.

Below we report calculations suggesting that during this 5-6 year period of labor market slack and very low inflation only between 0.5 and 1.7 percent of workers took a cut in regular nominal pay. These calculations seem to support the view of those macroeconomists who argue that wage rigidity is an important phenomenon, and that adjustments to adverse macroeconomic shocks may take a long time, perhaps up to a decade.

No doubt, the pervasive nature of wage rigidity can be partly attributed to country-specific regulations and bargaining institutions. The wage cuts that did occur took place in firms that were lowly unionized. The incidence of wage cuts was significantly higher in the skilled service sector, where collective bargaining agreements play a lesser role. We report evidence that unemployment benefits contribute to wage rigidity in the low-end of the labor market. Many managers indicate that Swedish employment protection creates important costs of hirings and firings, a result that vindicates a key assumption in Holden's $(1994,2002)$ analysis of nominal wage rigidity. In his model strict employment protection prevents firms from

\footnotetext{
${ }^{2}$ Except for Agell and Lundborg (2002) recent survey studies of wage rigidity have been conducted in periods when the activity level has fluctuated within normal intervals. Though Bewley (1999) began his interviewing towards the end of the US recession of the early 1990s, the depth and length of this recession is not at all comparable to the Swedish macroeconomic bust of the 1990s.

${ }^{3}$ According to the Labour Force Surveys of Statistics Sweden, the number of employees in manufacturing decreased by 24 percent between 1991 and 1994. In public administration the decrease was 19 percent between 1991 and 1995. In what we refer to as unskilled services (hotel and restaurants) employment fell by 16 percent between 1991 and 1993. For a broad discussion of the Swedish economic crisis of the 1990s, see Lindbeck (1997).
} 
dismissing workers who refuse to take a wage cut, and it is this legal feature that gives workers the strength to prevent the firm from implementing unilateral wage cuts.

Yet, much of our survey was specifically designed to explore the nature and sources of endogenous wage rigidity, i.e. rigidities that reflect general behavioral mechanisms unrelated to legal and bargaining institutions. We find substantial support for explanations linking work performance and voluntary turnover to wages, and we show evidence that a feeling of underpayment leads to a reciprocal effort response. Many managers indicate that their employees are subject to money illusion, and that workers care about relative wages. These results corroborate the findings of the studies of Table 1, based on much less representative samples. These results also corroborate recent experimental work, which has demonstrated that reciprocity and gift exchange play an important role in generating wage rigidity in experimental labor markets; see Gächter and Fehr (2001) for a survey. ${ }^{4}$

But we also document several novel results. First, our econometric analysis shows that the strength of the mechanisms of endogenous rigidity differs significantly between segments of the labor market. We report robust evidence that efficiency wage mechanisms involving work morale play a more important role in larger organizations. Managers in larger organizations are more prone to indicate (i) that that they have imperfect information about effort, (ii) that higher external wages reduce effort and (iii) that employees who feel underpaid reciprocate by reducing effort. We present results showing that the size-effect involving (ii) and (iii) is not due to insufficient monitoring capacity of larger organizations. The voluntary turnover mechanism is most important for the high-end of the labor market, where workers are highly paid and highly educated. It also appears that this particular mechanism is of greater concern for managers in regions with a large local labor market. Though most managers rejected the implication from the shirking model that higher benefits have a negative impact on work performance, this mechanism may play a role for the lowend of the labor market.

Second, the mechanisms of wage rigidity appear to complement each other. Worker-firm bargaining over wages (which may occur in union as well as non-union settings) and efficiency wage mechanisms are important independent causes of wage rigidity. Below, we report evidence that these mechanisms interact: firms in which

\footnotetext{
${ }^{4}$ Agell (1999) makes the point that the best way of acquiring empirical knowledge about the sources of wage rigidity is by combining the insights from the survey literature and the experimental literature.
} 
rent sharing play an important role are also firms where efficiency wage mechanisms appear to play a relatively important role. Similarly, unions and workers' concern about relative pay are often treated as independent causes of wage rigidity. Our analysis suggests, however, that workers' interest in external pay is robustly correlated with union density, and we conclude that relative wage theories of wage rigidity - following Keynes (1936, p. 14) - holds most promise for unionized sectors of the economy. As noted by Summers (1988) these kinds of interactions between mechanisms (seldom accounted for in theoretical models of wage rigidity) may magnify greatly the extent of wage rigidity.

The paper is organized as follows. Section 2 overviews our sample design. Section 3 briefly reviews institutional aspects of Swedish wage bargaining, and explains our statistical analysis. Section 4 presents our results on the incidence of nominal wage cuts. Section 5 contains our analysis of the mechanisms of wage rigidity, and presents our evidence on the complementary nature of mechanisms of wage rigidity.

The ensuing sections examine some issues in the economics of personnel. Section 6 reports evidence on the stigma from long-term unemployment, and on how the stigma correlates with strict job protection. An important novel finding is that we find evidence that job protection makes it more difficult for the long-term unemployed to re-enter the labor market. We also report evidence that labor market training appears to reduce the bias against the long-term unemployed. Section 7 shows that larger organizations rely on pecuniary incentive schemes to a significantly greater extent than smaller ones, and that there appears to be a complementary relation between firms' use of pecuniary reward schemes and "soft" incentives that try to promote good management-worker relations. Managers in smaller organizations have a significantly more negative attitude towards incentive schemes based on relative rewards. Finally, section 8 presents some preliminary evidence on how gender impacts on incentives, bargaining and work moral. 


\section{Sample and survey design}

\section{A. Sampling design}

Our sampling frame is the Business Register ${ }^{5}$ of Statistics Sweden, a register that includes the addresses to all enterprises that carry out (legal) activity in Sweden. It covers all forms of businesses, including limited liability companies, partnerships, associations, branch offices of foreign enterprises, etc. It covers businesses in all size classes, ranging from one-man firms to multinationals, and it includes addresses to all government bodies. For each unit there is continually updated information about the number of employees, sectoral affiliation at a very detailed level (the Swedish SIC code has five hierarchical classification levels), and geographical location. In 1999 the register contained the addresses to almost 800,000 independent firms (employing 4.1 million people), and to the 877,768 geographically separated local units where they conducted their activities.

As we wanted to explore wage-setting mechanisms at the level of the individual plant, and as officials at the head office of a large company might know less about pay at the local level, we chose the local unit as our sampling unit. Another consideration was what sectors to focus on. As we wanted to cast light on mechanisms discussed in the academic literature, we did not aim at a balanced coverage of all sectors. We rather wanted to include those sectors that provided sufficient variation to shed light on the theoretical arguments. For this reason, we included four sectors in our sampling frame: manufacturing, skilled services, unskilled services, and public sector administration (precise definitions, and SIC codes, are shown in the notes to Table 2).

We included the manufacturing sector in its entirety, since it has been at the center of attraction in previous field-research, and since it serves as a natural benchmark for our analysis. Skilled services (which comprises computer consulting, law firms, $R \& D$ institutes, and architect's offices) is of interest because it represents a segment of the labor market with complicated jobs and relatively high wages. It is also a sector where models of work-life incentives and tournaments might be of particular relevance. Unskilled services (which consists of restaurants and hotels) is of

\footnotetext{
${ }^{5}$ The Business Register is primarily based on information collected for administrative purposes. A main source of information is The National Patent and Registration Office, which maintains regularly updated addresses to all business units that operate in Sweden. Detailed information about the Business Register can be obtained from the web site of Statistics Sweden, www.scb.se.
} 
interest for the opposite reason. Because unskilled services represent a sector with simple jobs, that might be easy to monitor, one may suspect that the wage setting mechanisms look rather different, and that the forces of demand and supply play a more important role. Finally, it also seems worthwhile to pay attention to differences between wage setting in enterprises that operate under profit maximizing conditions and those that operate under other sets of constraints. For this reason we included public sector administration. After these exclusions we were left with 74,335 units, employing 1.23 million people (which is 30 percent of total employment).

An important consideration in deciding the sampling frame was how to deal with the smallest units, with less than five employees. Since their workforce often consists of relatives of the owner, standard models of wage determination need not apply. Moreover, based on their own experience, Statistics Sweden cautioned us that not even a substantial investment of our scarce research money would buy a satisfactory response rate for these units. We therefore decided to exclude all units with less than five employees. After these exclusions, we were left with 29,782 local units, divided among four sectors, and employing 1.141 million people. We divided these remaining units in three size categories, small ones with 5-19 employees, medium sized ones with 20-99 employees, and larger ones with more than 99 employees. The resulting twelve strata are shown in Table 2.

Cost considerations limited our total sample to 1200 local units. It is common to make sample size proportional to the total number of units in each stratum. In our case, however, a strict application of this principle implies that a very large share of the sample ought to be allocated to the units with less than 20 employees. But we would then face an obvious risk of getting less reliable responses from the largest units that may employ several thousand employees. In manufacturing, for example, there is a total of 14027 units, of which no less than 8745 (62.3 percent) belong in the smallest size category. At the same time, these units represent only 12.2 percent of total employment in this sector. To strike a balance, we in the end assigned a random sample of 100 to each stratum (our net samples deviate somewhat from this simple allocation because some units ceased operation between the time our sample was drawn and our questionnaire sent out). Since the total population of unskilled service units in the largest size category consisted of only 50 units, we reallocated 50 random drawings to the stratum consisting of small, manufacturing units. 
Our questionnaire was sent out in March 1999. After three written reminders, where the second one contained another copy of the questionnaire, the data gathering was called off in May. In all, we obtained 885 useable replies, which implies a response rate of 75.1 percent, much above the ones reported in Table 1. As can be seen in Table 2, public sector units have the highest response rate, and unskilled service units the lowest. Also, the response rate is higher among large units. Appendix 1 below reports an analysis of the potential non-response bias in our survey. Under the assumption that non-responders would have answered in exactly the same way as the late responders, who replied only after one or more reminders, we can predict the potential magnitude of the non-response bias. Based on this standard method of analyzing non-response bias, we conclude that the potential bias is quite small. This reflects two circumstances. First, the responses of late responders do not differ much from those of the immediate responders. Second, the percentage of non-response $(24.9 \%)$ in our survey is in fact quite low.

\section{B. Our questionnaire}

Appendix 2 contains an English translation of our questionnaire. All questions are closed ones, and we asked respondents to indicate their replies on an ordinal scale, with four or five options (the surveys of Agell and Lundborg (1995, 2002), Campbell and Kamlani (1997) and Levine (1993) follow the same pattern). The reason for this is that we wanted to quantify all answers, and that we judged electronic scoring to be the most reliable way of handling the completed questionnaires. A letter explaining the purpose of our survey accompanied the questionnaire. We promised that respondents' anonymity would be preserved, and we asked for the cooperation from the human resource manager, or "someone with corresponding experience of personnel policy and pay bargaining".

Some previous field research (e.g. Blinder and Choi (1990) and Campbell and Kamlani (1997)) asked respondents to react to a selection of theories of wage rigidity. Though a small number of our questions proceed in this manner, most of them concern concrete issues of work and pay. We emphasized that we were interested in understanding practices at the respondent's own unit, and we tried - like Bewley (1999) - to avoid hypothetical questions, or questions that required respondents to assess the general equilibrium implications of firm-level wage setting. 


\section{C. Matched worker-firm data}

We obtained most of our background information from Statistics Sweden. The Business Register contains information about the unit, when it began operation, its legal form, detailed sectoral classification, number of employees, etc. Our main source of information about employees is the employment register of Statistics Sweden, which includes the population of registered residents in Sweden. This register contains detailed demographic and educational data, and it has been augmented with information about taxable earnings and asset income, and about incomes from social insurance. Since the employment register contains information about the unit where people make their living, we could create a link between those units that filled out our questionnaire and their employees. Thus, for all but a handful of units we have detailed economic and demographic information about their employees.

Table 3 shows some descriptive statistics; there is clearly a lot of variation in our background data. Workers in manufacturing are predominantly male, lowly educated, and heavily unionized. Workers in unskilled services are predominantly female, young, lowly unionized, and often born in a non-Nordic country. They are also lowly educated, lowly paid and less prone to hold a permanent job contract. Workers in skilled services are highly educated, highly paid, lowly unionized and often covered by a scheme of profit sharing. Workers in public administration are heavily unionized, relatively old and highly educated, and nearly always born in a Nordic country.

\section{Some preliminaries}

\section{A. Swedish institutions}

Most Swedish employees have their pay determined in a two-stage process, where bargaining at the level of the firm follows bargaining between unions and employers' organizations at the level of the industry. Until the mid-1980s the local component played a lesser role, except for white-collar workers in the private sector. However, during the 1990s wage setting has become much more responsive to local conditions, 
and to the characteristics of individual employees. It is important to note that this move towards decentralization applies also for blue-collar workers. ${ }^{6}$

The Swedish Metalworkers' Union, which organizes more than 400,000 bluecollar workers, is a case in point. This central union signs an industry-level wage agreement that regulates the minimum average rate of wage increase at workplaces in the engineering sector. At the same time, the Metalworkers' Union delegates the determination of the pay of individual workers to bargaining at the workplace. As a consequence individual workers may in the end receive wage hikes that are considerably lower or higher than the rate of wage increase agreed upon at the industry-level. It is also of interest to note that the industry-level wage contract contains recommendations that the skills and competence of individual workers should be decisive factors in the local pay bargain.

Our survey is specifically designed to cast light on pay determination at the local level, i.e. bargaining involving the firm and the local union, and the firm and individual employees. Our survey sheds no light on incentives facing wage setters at the level of the industry, and it provides no information about aggregate bargaining interactions.

Though pay setting has become considerably more decentralized, it is important to note that Swedish labor law disallows employers the right to cut nominal pay unilaterally. This is so also in a situation when the old wage contract has expired. The old wage is treated as a part of the employment contract, which can only be modified by mutual consent. The inability of firms to reduce wages unilaterally derives from the Swedish Employment Security Act, LAS, which prevents firms' from dismissing employees unless there is just cause. ${ }^{7}$ Without this stipulation an employer would be unhindered simply to terminate the employment contract of employees who refuse to accept a wage cut.

In assessing the scope for nominal wage cuts it should also be noted that the industry-level wage contracts for blue-collar workers normally prevent the parties at the local level from striking deals that produce an average rate of wage growth below

\footnotetext{
${ }^{6}$ For an overview of the Swedish system of wage bargaining, see Nilsson (1992).

${ }^{7}$ Swedish labor law allows the firm to give its employees notice of quit if there is a "scarcity of work". This possibility strengthens a firm's bargaining position vis-à-vis its employees: if employees can be convinced that their jobs will be lost unless wage costs are reduced, they might accept to cut pay. In assessing the incentive to use the threat of redundancies to reap wage concessions, one must note that Swedish job protection legislation implies that layoffs must follow a strict seniority principle. A firm that declares a redundancy has no guarantee that it can keep its most productive workers.
} 
the minimum rate agreed upon at the industry-level. Unless the parties at the industrylevel have reached an agreement to cut pay it is therefore very difficult for the parties at the local level to implement a legally binding deal to lower average wage costs. ${ }^{8}$ For white-collar workers the industry-level agreements are normally more openended, and the parties at the local level often have the option to strike alternative deals. It is also important to note that union density is significantly lower among white-collar workers, and that there are segments (think of the new economy) of the labor market where two-tier bargaining plays little role.

Though many countries have laws that prevent unilateral wage cuts, and though two-tier bargaining is widespread in Europe, there is scant theoretical work on the macroeconomic consequences. An exception is Holden (1994, 2002), who shows that the requirement that firms must not unilaterally cut pay after an old contract has expired alters the threat points in the worker-firm bargain. He shows that this "aftereffect" of the old contract may generate substantial nominal rigidity. Holden (1998) analyzes two-tier bargaining, and he shows that the existence of a nominal wage floor at the industry-level implies that real wages become more rigid as inflation is reduced.

\section{B. Theories of endogenous wage rigidity}

A large literature has emphasized that wage rigidity might occur for intrinsic microeconomic and bargaining reasons, unrelated to unions and labor law. Representative approaches are e.g.:

(i) The insider-outsider approaches of e.g. Gottfries and Horn (1986) and Lindbeck and Snower (1988), in which the rent sharing of incumbent workers raises wages above the competitive wage level.

(ii) The efficiency wage approach, which predicts that firms for a variety of reasons (related to shirking, labor turnover, reciprocity, etc.) have an interest in raising wages above the level consistent with full employment. Some versions of this approach build on the idea that workers' loss aversion and money illusion lead to nominal wage rigidity.

\footnotetext{
${ }^{8}$ To the extent that both local employer and local union have a shared interest in cutting pay, they can engage in activities that circumvent the industry-level wage contract. In a small establishment it might not be very difficult to conceal a wage cut from the inspecting eyes of the central union. Similarly, a firm may reclassify workers into a lower job category. An alternative strategy is to change the remuneration system: workers agree to take a cut in their baseline pay, in exchange for bonus-pay, to be paid out at some unspecified future date.
} 
Evaluating the relevance of these and other theories has been a main purpose of the surveys shown in Table 1, and many of our own questions have the same motivation.

Below we will not always draw a sharp distinction between mechanisms generating real and nominal wage rigidity. As argued by Ball and Romer (1990) and Hanes (2000), in the presence of small frictions that make it costly to change nominal prices, the mechanisms that generate real rigidity will also generate nominal rigidity. Also, in an environment of near-zero inflation it is difficult to distinguish between mechanisms generating real and nominal rigidity. Finally, as noted by Campbell and Kamlani (1997, p. 764), the distinction between real and nominal wages has little meaning when asking firms why they do not try to lower wages during a recession, or how the structure of internal wages affect effort and morale. For these reasons, and because we were cautious not to trouble respondents with definitional issues, most of our questions deal with nominal wages.

\section{C. Our statistical analysis}

Many of our questions ask respondents to pick either of four or five options (e.g. "always, "often", "sometimes", "never"). We dichotomized these replies, so that each respondent was classified as belonging to either of two groups, those indicating that a certain phenomenon was common, and those indicating that it was less common. ${ }^{9} \mathrm{We}$ then performed a logit analysis, regressing the dichotomized response variable against a set of benchmark regressors. In alternative specifications we estimated ordered logit models (proportional odds), exploiting the full variation in our response variables. As we will see below most of the time it makes little difference to the results whether we estimate ordered or standard logit models.

Our benchmark regressors, shown in Table 4, measure the characteristics of employees with respect to age, gender, immigrant status and schooling. These are variables that belong in an ordinary wage equation. In our baseline specification we use three dummies to control for sectoral affiliation. We treat manufacturing as our comparison group, and include dummies for unskilled services, skilled services and public administration. We also report specifications where we introduce dummies for sectoral affiliation at a more detailed level, primarily based on the two-digit SIC code. There are two dummies indicating population density. We treat units in an area with 
high population density as the comparison group, and we view MEDIUMPOP and LOWPOP as indicators of the size of the local labor market. Finally, there is a dummy indicating whether a unit belongs to a multi-plant enterprise.

Our benchmark specification also includes variables that might be of particular relevance for students of wage rigidity. The first is the number of employees per unit, LOGSIZE. Size might be related to wage rigidity for various reasons. Large units may find it more difficult to monitor their workers, and wage rigidity may then be associated with size because efficiency wage/shirking mechanisms play a greater role in large units (Rebitzer and Robinson (1991)). Alternatively, if employee bargaining power is positively correlated with firm size, wages should be more rigid in large firms. One way of rationalizing such a correlation is by noting that to the extent that capital intensity is higher in larger firms, large firms will be more vulnerable to strikes and other disruptions of the work process. Because of this workers in large firms have greater power in the local wage bargain. ${ }^{10}$

To further explore the role of bargaining and unions we introduce two additional variables, the share of employees that belong to a union, UNIONDENSITY, and the share of employees that hold a permanent employment contract, PERMCONTRACT. The idea behind the latter variable is that workers' bargaining strength ought to be an increasing function of the share of employees who hold a permanent employment contract. One should note, though, that PERMCONTRACT is probably also correlated with the stock of firm-specific human skills. In firms where long-term employment relationships are common, there is a stronger incentive to invest resources in firm-specific skill formation; see e.g. Acemoglu and Pischke (1999) and Holden (2001).

To test the validity of our background data, Table 5 shows the results when we regress (average) earnings against our explanatory variables. All coefficients are precisely estimated, and in agreement with the microeconomic wage equations for Sweden reported in Albaek et al. (1998) and Arai (2001). As was the case in these studies the coefficient on LOGSIZE is positive, a result that remains as we bring in controls for sectoral affiliation at the two-digit level $(* *$ and $*$ denote significance at

\footnotetext{
${ }^{9}$ To gain precision in our econometric analysis we divided respondents in as equally sized groups as possible.

${ }^{10}$ Hanes (2000) uses U.S. data on wage changes by industries during the downturns of three major business cycles to examine the causes of wage rigidity, and argues that rigidity is the most pronounced
} 
the one and five percent levels). ${ }^{11}$ The coefficient on PERMCONTRACT enters with a positive sign, in line with the conjecture that permanent contracts ought to be correlated with employee bargaining strength and/or firm-specific skills. The variable UNIONDENSITY enters with a counterintuitive negative sign. ${ }^{12}$ Arai (2001) reports a similar result, and concludes that the negative union-wage effect reflects a selection of low-wage workers into unions. The point estimate of the coefficient on FEMALE in column 3 implies that an increase in the share of female employees by 10 percentage points (e.g. from .4 to .5) lowers average earnings by 4 percent.

\section{The incidence of nominal wage cuts}

The new macroeconomic regime established during the 1990s, with a large increase in unemployment, and a return of price stability, suggests a climate conducive to the downward flexibility of nominal wages. ${ }^{13}$ To assess the incidence of wage cuts, we asked respondents the following:

Have wages (regular hourly wage, monthly salary, piece wage, etc.) been reduced at any time at your workplace during the crisis years of the 1990s? (See Question 1a in Appendix 2.)

As shown in Table 6, 28 units replied in the affirmative, which implies that 3.2 percent of all units had experienced a regular wage cut. Wage cuts were the least common in the public sector (where only one unit had cut pay), and the most common in skilled services (12 units had cut pay). Simple $t$-tests reveal that wage-cutting units differ in important respects. First, they are significantly smaller; the average number of employees is 67.6 in the sub-sample of wage cutting units and 97.8 in the sample of non-cutters. Among the smallest units with less than 20 employees (300 units in all), 4.7 percent indicated some experience with nominal wage cuts. Among the largest

in capital intensive industries. He also shows that capital intensity is highly correlated with firm size. Unfortunately, we have no data on capital stocks for the firms included in our sample.

${ }^{11}$ For an overview of the evidence on the size-earnings effect, see Oi and Idson (1999).

${ }^{12}$ Though the coefficient on UNIONDENSITY in column 3 is precisely estimated, it is not large in absolute terms. The coefficient of -.127 implies that an increase in union density by 10 percentage points (e.g. from .5 to .6) lowers average earnings by 1.27 percent.

${ }^{13}$ During the twentieth century Sweden has experienced macroeconomic contractions with total unemployment (including those enrolled in labor market programs) reaching 12 percent or more on three occasions, 1921-22, 1931-33, and the 1990s. Across-the-board wage cuts were the rule rather than the exception in 1921-22, and common (but not extensive) in 1931-33. See Fregert (1994). 
units with more than 100 employees (283 in all), 2.1 percent indicated the same. Second, they are significantly less unionized; the average unionization rates of the two sub-samples are 52.8 and 71 percent, respectively. Third, wage-cutting units are significantly more prone to operate a profit sharing scheme with wide coverage; the average percentages of employees covered by profit sharing are 64.3 and 30.7 percent, respectively (these numbers are exclusive of the nonprofit, governmental, sector).

Twenty-one units provided us with information about the share of employees affected by the wage cut. Several of the units that had cut pay had done so for a quite small group of employees. ${ }^{14}$ If we confine attention to those units that replied that they, first, had cut pay, and, second, had done so for a majority of their employees, we arrive at the nine units shown in the second column of Table 6 . Seven of these nine units belong in the skilled service sector. Some respondents provided written comments that give some guidance on the circumstances surrounding their pay cuts. One manufacturing unit wrote that metal workers' union ruled out wage cuts for bluecollar workers, but that "white-collar workers on a somewhat higher level" had taken wage cuts. Another manufacturing unit replied that it had temporarily lowered pay by 8-9 percent in the early 1990s, but that the "money was paid back" as soon as the firm was back on its feet. One unit in skilled services wrote that pay had been lowered for white-collar workers who had been re-assigned to less qualified jobs.

Downward wage rigidity appears to be a pervasive phenomenon in Sweden. Although we cover a period of 5-6 consecutive years of very high unemployment and near-zero inflation, only 3.2 percent of our local units indicated that they had any experience with a cut in regular nominal pay. Since these units are concentrated to strata that are less important in terms of total employment, the incidence of nominal wage cuts is even lower from the perspective of the individual employee. In all, our twelve strata represent a population of 1.141 million workers. Some calculations show that our results on the incidence of wage cuts imply that no more than 1.1 percent of these employees experienced a regular wage cut during the slump of the 1990s (the $95 \%$ confidence interval for this estimate is $0.5 \%-1.7 \%){ }^{15}$

\footnotetext{
${ }^{14}$ Eight units replied that the wage cut had affected less than 10 percent of their employees, four units that the wage cut affected between 10 and 40 percent of their employees, and nine units that the wage cut affected more than 70 percent of their employees.

${ }^{15}$ In deriving these numbers, we proceeded as follows. For each sampled unit that had existed at least since January 1994, and thus had been in operation during the severe recession, we computed the number of employees who had experienced/not experienced a nominal wage cut. For units that provided no information about the share of employees who received a wage cut, we simply invoked the
} 
For comparison, Agell and Lundborg (2002) find that not a single one of the 159 large manufacturing firms that they surveyed had implemented a comprehensive wage cut during the years of the crisis. Our stratum of large manufacturing units consists of 83 units; two of these indicated that they had cut pay, but none of them had done so in a comprehensive manner. Ekberg (2002) studies the incidence of wage cuts in the Swedish private sector using establishment-level data collected by the Confederation of Swedish Industries. He focuses on the development of the "baseline hourly wage", and he considers annual wage changes for employees that stay on the same job. His results for white-collar workers are quite comparable to the ones we report here; between 1996-99 1.15 percent of all white-collar workers received a cut in baseline pay. Like us, he also finds that the incidence of wage cuts is significantly higher among smaller firms. ${ }^{16}$

A number of studies have examined the extent of wage rigidity in other countries. Fortin (1996) reports that during the Canadian recession of the early 1990s, when inflation averaged 1.2 percent and unemployment reached 11 percent, 5.7 percent of non-union settlements without cost of living adjustments included nominal wage cuts. ${ }^{17}$ Evidence suggesting that nominal wage rigidity is an important phenomenon has also been reported for Switzerland by Fehr and Goette (2000), and for Germany by Beissinger and Knoppik (2001). Smith (2000) presents evidence suggesting that nominal wages in Britain are quite flexible. The U.S. evidence is voluminous, and somewhat conflicting. McLaughlin (1994) concludes that wage

average share $(42.8 \%)$ for units that provided this information. To aggregate to the population level, we used the information about each stratum's share of total employment. In computing the $95 \%$ confidence interval (defined by the the $2.5^{\text {th }}$ and $97.5^{\text {th }}$ percentiles) for the statistic we generated a bootstrap distribution with 10000 elements.

The numbers presented in the main text are not very sensitive to the assumptions made. If we assume that the average share of employees who experienced a wage cut is 20 rather than 42.8 percent in units that did not provide this information, the estimated share of employees who experienced a wage cut falls to 0.89 percent. Raising the average share of employees who experienced a wage cut to 60 percent increases the same estimate to 1.26 percent. We also repeated the calculation including also those units that had begun operation between 1994 and 1998. The estimated percent of employees that had experienced a nominal wage was then $1.18(0.60 \%-1.88 \%)$.

${ }^{16}$ Ekberg's results for blue-collar workers are more puzzling. For the period 1997-98 he reports that 19.4 percent of blue-collar workers received a cut in baseline pay. In assessing this finding it is important to note that during the second-half of the 1990s the industry-level wage agreements for bluecollar workers were designed in a way that in effect ruled out cuts in nominal baseline pay (see our discussion above). Based on this fact we would certainly expect cuts in nominal baseline pay to be less common among blue-collar workers than among white-collar workers. As pointed out by Ekberg the high incidence of nominal wage cuts among blue-collar workers is most likely an artifact of measurement errors in the raw data (misreporting of work-hours, confusion of flexible and fixed components of pay, confusion of retroactive pay and regular pay hikes, etc). 
rigidity is an unimportant phenomenon, while Akerlof, Dickens and Perry (1996) suggest that this finding is due to measurement errors in the raw data. Using establishment data Lebow, Saks and Wilson (1999) report evidence of nominal wage rigidity, and Baker, Gibbs and Holmstrom (1994) report an almost complete absence of nominal wage cuts.

Because data sources and methodology differ between studies, it is not easy to compare the extent of nominal wage rigidity in different countries. Even so, it seems safe to conclude that Sweden is one of the countries where nominal wage cuts are the least common. In this context it is important to note that our results on the incidence of wage cuts in Sweden were registered during a prolonged period of severe economic slack and very low inflation. With the possible exception of the evidence for Canada and Switzerland, studies for other countries concern periods with stronger macroeconomic performance.

\section{The sources of wage rigidity}

Why are wages so rigid? This section presents our survey evidence with a direct bearing on the mechanisms of wage rigidity.

\section{A. Bargaining institutions}

As discussed in Section 3 Swedish wage bargaining institutions can be expected to generate a substantial amount of nominal wage rigidity. Since Swedish job protection legislation prevents firms from imposing unilateral wage cuts, wage concessions only ought to take place in firms where a major part of the jobs is at stake. Moreover, the system of two-tier wage bargaining makes it difficult for the parties at the local level to cut pay. The following observations suggest that these institutions may help to explain the low incidence of wage cuts in our sample.

First, evidence reported below shows that most firms believe that Swedish job protection creates important costs of hirings and firings. This finding vindicates the key assumption in Holden's $(1994,2002)$ analysis of labor law as a basic source of wage rigidity. In his model, a wage cut requires a mutual agreement between firm and

\footnotetext{
${ }^{17}$ Christofides and Stengos (2000) analyze the wage-change distributions in Canadian union contracts between 1976-1999, and find evidence of pronounced nominal rigidity.
} 
union or worker. Furthermore, the firm is not allowed to fire the worker, and then to offer a new job at a lower wage. It is the combination of these two legal features that gives workers a strategic advantage when they try to prevent a cut in nominal wages.

Second, two-tier wage bargaining is the least common in the skilled service sector. At the other extreme is the public sector, where collective wage bargaining is the rule. Based on this, we would expect the incidence of wage cuts to be significantly lower in the public sector than in the skilled service sector. A statistical test of the frequencies reported in Table 6 shows that this is indeed the case. Third, as noted in Section 4 union density is significantly lower in the sample of wage cutting units. Since union density can be expected to be a good indicator of the importance of twotier bargaining, this discrepancy between the two samples is another indication that collective bargaining matters for wage rigidity.

Finally, it is instructive to compare our results with corresponding ones for Switzerland, a country with different labor market institutions but a similar macroeconomic experience. In Switzerland firms are allowed to fire workers who refuse to accept a lower wage. As suggested by Fehr and Goette (2000, p. 4), “...the Swiss labor market is perhaps closer to the US labor market than to the labor markets in most other European countries." Moreover, in the 1990s Switzerland went through a recession almost as severe and prolonged as the Swedish one, with several consecutive years of very low nominal GDP growth. ${ }^{18}$

Fehr and Goette (2000) find that downward wage rigidity in Switzerland is a robust phenomenon. Despite a depressed labor market, and despite that Swiss firms can impose unilateral wage cuts, many workers received wage freezes instead of cuts. Evidence from two large Swiss firms suggest that roughly one percent of workers received wage cuts during each year of the crisis. This is roughly comparable to our own estimate for Sweden, suggesting that between 0.5 and 1.8 percent of workers received a wage cut. Our numbers, however, apply for a representative sample of

\footnotetext{
${ }^{18}$ Swiss GDP growth was negative between 1991 and 1993 (as it was in Sweden), and between 1994 and 1996 real growth was always less than 0.5 percent, see Fehr and Goette (2000). Between 1993 and 1997 the inflation rate was never above 1.6 percent. Though these figures are roughly comparable to the Swedish ones (see our Introduction), the Swedish recession was accompanied by much more substantial slack in the labor market. According to the standardized unemployment definition of the OECD (which gives an incomplete coverage of workers enrolled in various labor market programs), unemployment in 1990 was 0.5 percent in Switzerland and 1.7 percent in Sweden. In 1993 standardized unemployment was 4.0 percent in Switzerland and 9.1 percent in Sweden, and in 1997 (which is the year when unemployment peaked in both countries) the corresponding figures were 4.2 and 9.9 percent, respectively. (Source: OECD (2000)).
} 
firms, and they show the percentage of workers that received a wage cut at least once during the complete time span of the Swedish recession. When Fehr and Goette turn to evidence from more representative sources, they find - after correcting for measurement errors in their raw data - that between 2.3 and 6.4 percent of all workers received a wage cut during each year of the Swiss recession. Thus, while wage rigidity was nearly complete in our sample wage cuts were considerably more common in Switzerland. This result is consistent with the view that institutions can lead to downward wage rigidity.

\section{B. Wage competition from the unemployed}

Downward rigidity of hiring pay during a recession could be due either to the absence of active wage competition from the unemployed, or to firms' unwillingness to hire underbidders. Solow (1990) argues that the former reason is the more important one, and that there is a social norm preventing the unemployed from underbidding. The empirical evidence is scant, and inconclusive. Both Agell and Lundborg $(1995,2002)$ and Bewley (1999) report that underbidding is uncommon, but not unheard of.

An explicit offer to work for a wage which is lower than the going one is perhaps not the most obvious method of underbidding incumbent employees. There are subtler but equivalent strategies that can be adopted by an unemployed worker who wants to undercut existing jobholders. To quantify the frequency of undercutting in this broad sense, we asked respondents the following:

Does it happen that your workplace is approached by job seekers who offer to work under conditions that are inferior (lower pay, less convenient hours, poorer work environment, etc.) to those you normally offer new employees with corresponding qualifications? (Question 3a)

Because of the general phrasing of the question, we expected many firms to answer our question in the affirmative. But this was not the case, as can be seen in Table 7. Though some units indicated that job seekers sometimes offer to work at lower (effective) pay, underbidding appears to be uncommon in all our strata. In all, only 119 units (13.5 percent) indicated that they had encountered underbidders. The incidence of underbidding is highest among small units in unskilled services (22.7 percent), and lowest among large units in skilled services (6.8 percent). This low 
incidence appears roughly consistent with Solow's conjecture that there is a social norm that keeps the unemployed from underbidding. ${ }^{19}$

It is equally striking to note that 90 percent of the respondents who had been contacted by an underbidder had always rejected the offer, see Table 7. Bewley (1999) reports that most of the managers he interviewed rejected low-wage offers, and Agell and Lundborg (1995) find the same tendency in their survey of Swedish manufacturing. Here, we find that rejection of underbidders is a general phenomenon, pertaining to firms in all sectors, and in all size ${ }^{20}$ categories. We asked respondents to rank the reasons for rejection; see Table 8. For units in manufacturing and skilled services, concerns about personnel policy and internal conflict were ranked as the most important factors, i.e. factors emphasized in some efficiency wage models, and in some insider-outsider models (see Lindbeck and Snower (2001)). For public sector units, unions and the collective bargaining contract were far more important (it should be noted that union density exceeds 90 percent in all public sector strata, see Table 4).

We conclude that lack of wage competition is probably not a main reason why wage cuts were so rare during the macroeconomic bust. While underbidding is uncommon, firms' nearly always reject such offers. ${ }^{21}$ Judged against these rejection rates, the low incidence of underbidding is not surprising. We conclude that understanding the reasons for wage rigidity at the hiring margin requires that the searchlight is aimed at the firm and its incumbent employees, rather than at the unemployed job seeker. In this context it is suggestive that less than five percent of managers who rejected underbidders pointed to the explanation "underbidders have inferior skills", see Table 8.

\section{C. Wages, monitoring and effort}

Some of our questions were designed to shed light on how managers perceived the link between wages and effort, and to what extent the strength of these mechanisms depended on the characteristics of firms and workers. A basic consideration in models

\footnotetext{
${ }^{19}$ The low incidence of underbidding is also consistent with the observation that the Swedish welfare state reduces substantially the income loss from unemployment. For data on net replacement rates in Sweden and other OECD-countries, see OECD (1999).

${ }^{20}$ Among units with less than 20 employees, the rejection rate is 90.2 percent, and among units with more than 200 employees it is 86.7 percent.

${ }^{21}$ Fehr and Falk (1999) report results from experimental labor markets, suggesting that firms refuse to hire underbidders. Dufwenberg and Kirchsteiger (2000) study a wage setting game, in which workers are motivated by reciprocity. In their model the firm rejects underbidders in equilibrium.
} 
of motivation is whether firms can observe work performance. When we asked, "to what extent can you evaluate whether a specific employee performs satisfactorily on the job?", 50.7 percent indicated that they could evaluate performance "to a very great extent", and 49.3 percent indicated that they were less than certain about performance.

Table 9 reports our logit analysis (conducted along the lines outlined in Section 3C) of the determinants of employers' ability to appraise performance. Column 1 shows that the coefficient on LOGSIZE is negative and highly significant. We obtain similar results (see column 2) when we regress respondents' assessment of their ability to appraise team performance against the same variables. The inverse relation between unit size and ability to appraise work performance is robust, surviving a range of sensitivity tests reported below. Few of our other benchmark regressors turned out to be statistically significant. Local unions might interfere with the monitoring strategies of firms, highly educated workers normally hold more complicated jobs that can be expected to be more difficult to monitor, etc. However, neither of UNIONDENSITY nor UNIVERSITY was remotely close to statistical significance (results not shown). Among our sectoral controls, the coefficient on PUBLIC is negative and highly significant - compared to managers in manufacturing, those in public units are significantly less able to appraise work performance. The coefficient on FEMALE is positive and statistically significant in column 2, but this result disappears once we introduce finer sectoral controls. As we will see in Section 8, there are other partial correlations involving FEMALE that appear to be robust.

Most efficiency wage models predict that changes in external wages have an impact on work effort. This is true of the canonical shirking model of Shapiro and Stiglitz (1984), and it applies for those versions of the gift-exchange model of Akerlof (1982) in which workers' norms of comparison extend to workers in other firms. We asked respondents how they thought that an increase in external wages would affect effort at their own unit. As can be seen from Figure 1 a great majority (581 out of 882 respondents) thought that higher wages in comparable companies or organizations would lower effort at their own unit. ${ }^{22} \mathrm{We}$ view this as a strong indication that most firms perceive themselves to have an incentive to maintain external wage relations.

\footnotetext{
${ }^{22}$ Only eight percent of our respondents indicated that lower unemployment would reduce effort. Agell and Lundborg $(1995,2002)$ report substantial evidence that increased unemployment leads to increased effort. A reconciliation of these responses, obtained in years with low (1991) and high (1999) unemployment, is that unemployment has a stronger effect on effort when unemployment is low. Other
} 
This finding differs radically from the results of Campbell and Kamlani (1997) and Bewley (1999). Though these surveys report significant evidence that effort and work moral respond to internal pay and internal pay structures, external pay appears to play little role. In Section $5 \mathrm{G}$ we show results suggesting that the high union density in Sweden can explain these differences between countries.

Our finding that managers in small units find it easier to evaluate performance suggests that size might also matter for the link between outside wages and effort. This is precisely what we find, see column 3 of Table 9. Managers in large firms are significantly more prone to identify a negative link between external wages and effort.

A large experimental literature suggests that reciprocity is an important motivational factor in the labor market, and that workers who feel that their pay is unfair respond by reducing effort, see Fehr and Gächter (2000) and Gächter and Fehr (2001). We asked: "In your opinion, do those of your employees who are dissatisfied with their pay normally reduce performance?". Forty-nine percent of our respondents (427 managers) answered in the affirmative, 28.9 percent answered that such a response was possible but not common, while 22.1 percent ruled out the possibility altogether. Table 9, column 4, reports our econometric analysis of the link between effort and wage dissatisfaction. Again, there is a highly significant coefficient on LOGSIZE, suggesting that managers in large units are more inclined to believe that disgruntled workers reduce effort. We also find an intriguing gender effect (see Section 8 for further analysis); the negative and highly significant coefficient on FEMALE seems to suggest that managers with a large share of female employees worry less about negative reciprocity.

Is the size effect robust? Table 10 shows our sensitivity analysis. Row 1 reproduces the estimated coefficients on LOGSIZE from Table 9. In row 2, we can see that the Spearman rank correlations between the left-hand side variables and LOGSIZE are highly significant. Row 3 shows the results from a procedure of stepwise elimination of insignificant explanatory variables (starting with the full set of regressors of Table 4). According to this procedure, LOGSIZE always belongs in the final set of significant explanatory variables. Row 4 shows the consequences of adding more information about the left-hand side variables. Instead of dichotomizing respondents' replies to our questions, we exploit all the variation of the original 
answers and proceed by estimating ordered logit models. LOGSIZE remains significant at the one percent level in all columns.

Row 5 shows the results when we replace LOGSIZE with dummy variables for small and medium-sized units (units with more than 100 employees constitute the reference category). In all columns the dummy for the smallest units, with less than 20 employees, is significant at the five-percent level. However, the dummy for the category of medium-sized units is only significant in columns 2 and 4 . Rows 6 and 7 show the results of re-estimating our basic model for various subsets of our full sample. The coefficients on LOGSIZE are estimated with much lower precision as we drop all small- and medium-sized units. In row 7, all coefficients are insignificant at the five percent level, and two of them change sign. Thus, the reason we identify a size-effect appears to be that our survey includes a reasonably sized sample of units with less than 100 employees.

How should one interpret these size-effects? A tempting explanation for our empirical results is as follows. Assume that large organizations have greater difficulties in monitoring work effort than smaller ones. The canonical shirking model would then lead us to believe that work effort in larger organizations is more responsive to external pay. Because of the inferior monitoring capacity of larger organizations we would also expect such organizations to find it more difficult to prevent acts of negative reciprocity. However, some specification tests suggest that this explanation is probably wrong, or at least too simplistic.

If the coefficients on LOGSIZE in Table 9 only capture the inferior monitoring capacity of large firms they would not remain significant if we added a direct measure of monitoring capacity to the estimating equation. In Table 11, column 1, we reproduce the statistically significant coefficient on LOGSIZE from the equation describing the relation between external pay and effort in Table 9. In the second column we report the results when we include MONITOR1, (managers' own assessment of their ability to evaluate individual effort, a variable constructed from Question 5a) among our regressors. In column 3 we rather include MONITOR2 (managers' assessment of their ability to evaluate team effort, constructed from Question 5b). In columns 4-6 we examine how the introduction of MONITOR1 and MONITOR2 affect the coefficient on LOGSIZE in the equation describing the relation between pay dissatisfaction and effort . The coefficients on MONITOR1 and MONITOR2 have the negative sign predicted by the shirking model, and in column 3 
the coefficient on MONITOR2 is statistically significant at the one percent level. However, LOGSIZE remains significant in all specifications, though the significance levels decrease somewhat as we add the monitoring variables. We conclude that LOGSIZE and our two monitoring variables primarily capture different mechanisms, and that our finding that external pay and reciprocity matter more for effort in larger organizations is not primarily due to the insufficient monitoring capacity of larger organizations.

Summing up, the results of this section show that many human resource managers believe that effort and work moral is responsive to firm's wage policy, as predicted by efficiency wage theory. Two-thirds of our respondents believe that a ceteris paribus increase in outside wages damages performance at their workplace, and almost fifty percent indicate that employees who are dissatisfied with their pay normally reduce effort. We have also identified a robust size-effect: human resource managers in larger organizations know less about work performance, indicate that increases in external wages have a stronger adverse effect on effort, and are more inclined to believe that workers who feel lowly paid reduce effort.

\section{D. Wages and voluntary turnover}

An important result of Campbell and Kamlani (1997) is that wages are kept rigid out of fear that wage cuts would increase quits and labor turnover, and that this mechanism is most important for white-collar workers. We asked, "In your opinion, do those of your employees who feel unhappy about their pay normally seek employment elsewhere?”. Out of 880 responding managers, 58.5 percent replied in the affirmative, 29.4 percent indicated that voluntary turnover was possible but uncommon, while 12.1 percent ruled out this possibility altogether. From these responses it is hard to escape the conclusion that managers perceive the risk of voluntary turnover as an important constraint on their wage policy.

Table 12 reports our results on the determinants of the risk of quits. Column 1 shows our benchmark logit specification, column 2 introduces two-digit controls for sectoral affiliation, and column 3 shows the results from an ordered logit regression, which restores the original variation in the response variable. Most of the partial correlations make intuitive sense. The positive coefficient on UNIVERSITY indicates that the risk of quits is greater in units with a large share of highly educated 
employees. The negative coefficient on LOWPOP suggests that the risk of quits is significantly lower in areas with a small local labor market. The negative coefficient on PERMCONTRACT (which is only significant at the ten percent level in columns 1 and 2) implies that the risk of quits is lower in case of tenured employees. To the extent that firm-specific skills are greater in units with employees on permanent contracts, this correlation is what we would expect. It is not obvious how to interpret the negative coefficient on UNIONDENSITY, suggesting that the risk of voluntary turnover is smaller in highly unionized firms. It is useful, though, to recall Arai's (2001) finding that there appears to be a selection of low-wage workers into unions in Swedish microeconomic data. Based on this, one may conjecture that the negative coefficient reflects the possibility that dissatisfied union members have worse outside options than dissatisfied nonunion workers.

Summing up, many managers see a link between wages and voluntary turnover. This mechanism of wage rigidity appears particularly relevant for the highend of the labor market, i.e. for firms with a workforce that is highly educated, lowly unionized and have access to a large local labor market.

\section{E. Benefits and effort}

The shirking model of Shapiro and Stiglitz (1984) predicts that more generous unemployment benefits induce workers to slacken off. We asked: "How do you think that the work effort of your employees would be affected if unemployment benefits were increased?". Though a large majority believed that higher external wages led to lower effort, few respondents thought the same of higher benefits. Among 876 respondents, only 125 (14.3 percent) replied that more generous benefits would induce their employees to reduce effort. Further inspection shows that benefits might still play a relatively important role for the low-end of the labor market. While only 8.3 percent of firms in the skilled service sector believed that higher benefits would reduce effort, 28 percent of firms in the unskilled service sector responded the same.

Table 13 shows our statistical analysis of the link between effort and benefits. The coefficients on PERMCONTRACT and BASICSCHOOL are highly significant across specifications. According to the specification in column 1 firms with a large share of employees on temporary contracts, and with a large share of lowly educated workers, are significantly more prone to identify a negative link between benefits and 
effort. These partial correlations remain significant as we introduce controls for sectoral affiliation in column 2 . Workers who are lowly educated and hold temporary contracts are also lowly paid, and column 3 shows that the coefficient on LOGEARNING is negative in a one-explanatory-variable logit regression: firms with below-average earnings are significantly more likely to indicate that benefits play a role for effort. In column 4 we add LOGEARNING to our benchmark explanatory variables. Since our benchmark set includes all the variables that appear in a conventional earnings-equation, it is no surprise that the coefficient on LOGEARNING is small, and imprecisely estimated. PERMCONTRACT and BASICSCHOOL remain significant.

On the whole, we do not find much evidence that unemployment benefits create wage rigidity via their impact on work morale and effort. But benefits might play a significant role for the low-end of the labor market. For this segment of the labor market, where wages are low and temporary contracts more common, we can not rule out that the benefit system is an important source of wage rigidity.

\section{F. Rent-sharing and bargaining strength}

A large class of models links unemployment and wage rigidity to the bargaining power of incumbent workers. An implication of all these models, which differentiates them from e.g. the competitive model and models of efficiency wages, is that workers capture a share of the firm's surplus in the bargain. We asked:

How common is it that your employees (or their union representatives) require wage hikes because of high profits, or high ability to pay, in your firm/organization? (Question 10c)

The answers suggest that profits/ability to pay is an important factor in manufacturing and skilled services, but a more marginal factor in unskilled services and the public sector. In manufacturing and skilled services 43.5 and 48.2 percent of respondents indicated that workers always/frequently/sometimes require higher wages in times of high profits/ability to pay. In unskilled services and public administration, the corresponding numbers were 20.9 and 17.0 percent, respectively.

We used the replies to Question 10c to create proxy-variables for the rent sharing, or bargaining strength, of employees. The argument is that in a firm where 
the employer has all the bargaining power workers would never require higher wages because of high profits/ability to pay, while the opposite would apply in a firm where workers have all the bargaining power. Our first proxy variable is constructed from the dichotomized responses to Question 10c, i.e. we divide units in two groups depending on whether profits/ability to pay is a common or less common ingredient in the local wage bargain. Our second proxy variable utilizes the full variation in the original answers. It should be noted that both proxy-variables are significantly correlated with the measure of earnings used in Table $5 .^{23}$

Our econometric analysis of the determinants of rent sharing is shown in Table 14. Of the three variables that we expected to be correlated with rent sharing, LOGSIZE is positive and significant at the one percent level in all specifications. The coefficients on UNIONDENSITY and PERMCONTRACT have the expected positive sign, but the standard errors are large. Though UNIONDENSITY is not significant in any specification, PERMCONTRACT is significant at the five percent level in columns 3-4. We also identify a highly significant gender effect, to which we return in Section 8 below: respondents in firms with a large share of female employees are less prone to indicate that rent sharing is an important factor in the local wage bargain.

We asked respondents to assess the empirical relevance of one particular bargaining model, the labor turnover version of the insider-outsider model (see e.g. Lindbeck and Snower (2001)). We presented the model in the following way:

One theory to explain why wages may end up above the level that gives full employment is based on the notion that hirings and firings are costly to firms. These costs (for interviews, advertisements, training, redundancy payment, etc.) make firms eager to keep already employed workers. By pushing up wages, this situation is exploited by employees. (Question 12b.)

Compared with Keynes's explanation of wage rigidity (discussed shortly) the insideroutsider model received a low score. Though our questions on job protection indicate (see below) that many managers believe that costs of hirings and firings are nontrivial, only 14 percent of our respondents indicated that the model coincided "completely" or

\footnotetext{
${ }^{23}$ The Spearman correlation between our first proxy and LOGEARNING is .215, and the correlation between the second proxy and LOGEARNING is .264. The significant (partial) correlations remain as we bring in sectoral and geographical controls in OLS earnings-equations (i.e. the kind of regressions that we report in Table 5). However, adding LOGSIZE (a variable that we for a priori reasons thought of as an indicator of bargaining strength) and other variables according to Table 5 to the estimating
} 
"to a great extent" with their own experience. Fifty-two percent even dismissed the insider-outsider model as having little or no resemblance with their own experience. ${ }^{24}$

Summing up, except for managers in the public sector and unskilled services many respondents indicated that the wage claims of their employees are responsive to profits and ability to pay. This finding is consistent with a main implication of a large class of bargaining models of unemployment and wage rigidity, but it is at odds with the competitive model. ${ }^{25}$ Another finding is that our indicators of rent sharing and worker bargaining strength are robustly correlated with firm size.

\section{G. Workers' wage norms and Keynes's explanation}

A classic explanation of wage rigidity is the argument of Keynes (1936, p. 14) that workers care about relative wages. Because of this they oppose money wage cuts, unless wages can be cut in a coordinated manner throughout the economy. If such interpersonal wage comparisons are to explain more than a trivial amount of wage rigidity, they should extend beyond workers in the same firm. Surveys among U.S. managers suggest however that employees mainly pay attention to the internal wage structure. Campbell and Kamlani (1997, p. 780) conclude that workers' notion of fair pay depend on own past wages, firm's profits, and wages of other workers in the same firm. Bewley (1998, p. 485) argues that Keynes's relative wage theory is off the mark, since workers in the firms he approached had "...little systematic knowledge of pay rates at other firms".

In sharp contrast to this evidence, most of our respondents indicated that both internal and external wages were important norms of comparisons in the local wage bargain (Question 10a-b). Across all strata, 47.3 percent indicated that internal wage comparisons "always" or "frequently" played an important role, and 41.8 percent said the same about external wages. This result agrees with Agell and Lundborg (1995,

equation is enough to drastically alter the point estimates of the coefficients on both proxy-variables. At the same time their significance levels drop substantially.

${ }^{24}$ Our econometric analysis, not shown, indicates that respondents in small units, and in units with a highly educated workforce, had a more positive appreciation of the insider-outsider model. Since fixed hiring and firing costs ought to be of greater concern for small units, and since it is more costly to recruit and train educated workers than uneducated ones, these partial correlations are what one would expect.

${ }^{25}$ Holmlund and Zetterberg (1991) find that rent sharing and insider forces are weak in Swedish wage setting. They focus, however, on a period (1965-85) characterized by nationwide pay setting. The aforementioned microeconometric study of Arai (2001) shows, in line with our findings, that rent sharing is an important factor. 
2002), who report that managers in their sample of large manufacturing firms believed that their employees cared both about internal and external wages.

What can explain the greater role of inter-firm wage comparisons in Swedish field surveys? Agell and Lundborg (2002) conjecture that unions play a role, because they can be expected to disseminate information about pay and pay scales across firms, and across industries. Bewley (1998, p. 485) describes his non-union firm as "isolated islands", where workers know little about external pay. Interestingly, he also observes that the precision of the information about external pay appears to be higher among workers in unionized firms.

Table 15, columns 1-4, shows our econometric analysis of the determinants of workers' wage norms. The most persistent finding is indeed that UNIONDENSITY is positively and significantly correlated with the intensity of both internal and external wage comparisons in the local wage bargain. Stepwise regressions (not shown) show that the coefficients on UNIONDENSITY remain significant as we change the set of conditioning variables. The coefficient on UNIVERSITY is positive and significant at the five percent level in columns 3 and 4, which suggests that external wages play a greater role in units with a large share of highly educated employees. This result agrees with Andrews and Henry (1963), who report that interest in external pay increases with the job level, and with Agell and Lundborg (1995), who report that senior white-collar workers pay greater attention to external wages. Among other results, it can be noted that internal wages appear to play a more important role in larger organizations (the coefficient on LOGSIZE is significant at the one percent level in columns 1 and 2), and that external wages appear to play a lesser role in units with a large share of female employees (the coefficient on FEMALE is significant at the one percent level in columns 3 and 4). Finally, the coefficient on PUBLIC is positive and highly significant in column 1, which indicates that public employees pay greater attention to internal wages than those in manufacturing. ${ }^{26}$

We obtained additional indications that Keynes's explanation of wage rigidity holds more promise for unionized economies when we asked respondents to assess how well the following coincided with their own experience:

\footnotetext{
${ }^{26}$ This result is consistent with the observation that public disclosure legislation in Sweden makes it easy for public employees to acquire information about the pay of their co-workers.
} 
Some researchers argue that the reason why wages seldom fall is that wage relativities might be altered. Employees try to protect their position in the wage hierarchy, and they resist wage cuts because they are afraid that they will fall behind other employees, at their own or other units. (Question 12a.)

Among our respondents 48.5 percent indicated that this mechanism coincided "completely" or "to a great extent" with their own experience. Table 15, columns 5-6, shows that there is a significant partial correlation between UNIONDENSITY and respondents' appreciation of Keynes's theory.

\section{H. On the complementarity between mechanisms of wage rigidity}

Theoretical models of wage rigidity typically deal with one complication at a time, and different theories are often treated as alternatives to each other. Unions and workers' concern over relative wages are often treated as independent sources of wage rigidity. Similarly, a large (primarily European) literature has emphasized the role of worker-firm bargaining over wages (which may occur in union as well as nonunion settings), while an equally imposing (primarily US) literature has emphasized the role of efficiency wage mechanisms.

As noted by Summers (1988), it is probably more fruitful to view these theories as complementary and mutually reinforcing explanations for wage rigidity. Summers argues that considerations of relative wages and efficiency wages magnify greatly the effects of worker/union bargaining power. First, in an "...efficiency wage environment, firms that are forced to pay their workers premium wages suffer only second-order losses. In almost any plausible bargaining framework, this makes it easier for workers to extract concessions" (Summers (1988, p. 386)). Second, he notes that whenever workers' care about external pay, the presence of insider bargaining power in some sector will have spillover effects on wages in other sectors.

Many of our findings appear to corroborate Summer's conjecture about the complementary nature of theories of wage rigidity. We have reported evidence that unions increase awareness about wage relativities. Moreover, establishment size is strongly correlated with indicators of bargaining strength and with indicators of effort and reciprocity, a coincidence that suggests that the mechanisms of efficiency wages and bargaining may interact.

To further explore the possible interactions between mechanisms of wage rigidity we computed the Spearman rank correlations between the replies to all our 
questions that relate to effort and relative wages on the one hand, and those that relate to bargaining and rent sharing on the other. There were five response options to these questions, and before computing the Spearman correlations we coded the responses on an integer scale 1-5, with 1 indicating that the mechanism in question was an important one, and 5 that the mechanism was unimportant. The results are shown in Table 16. The estimated correlations are all positive, and - with one exception statistically significant. On average, those respondents who indicate that mechanisms of bargaining and rent sharing play a relatively important role in the local wage bargain are also the ones who attribute a relatively important role to efficiency wages and wage relativities.

\section{I. Money illusion}

A classic way of explaining wage rigidity is with reference to money illusion, which is often taken to mean that agents for some reason have preferences defined over nominal rather than real outcomes. The surveys of popular attitudes of Kahneman, Knetsch, and Thaler (1986) and Shafir, Diamond, and Tversky (1997) suggest that money illusion is an important phenomenon. Similarly, Bewley (1999) observes that many managers were convinced that their employees would consider a nominal wage cut as highly unfair, even as an insult.

We asked our wage setters to react to the following scenarios, adapted ${ }^{27}$ from Kahneman, Knetsch, and Thaler (1986, p. 731):

Scenario 1 (872 respondents). Assume hypothetically that your enterprise is making a small surplus. There is no inflation, and unemployment is high. There are many job seekers applying for a job at your unit. Under these circumstances you decide to propose a pay cut of 5\%. How do you think that your employees would find this proposal? (Question 13a.)

Acceptable $\quad 5.7 \% \quad$ Not acceptable $\quad 94.3 \%$

\footnotetext{
${ }^{27}$ In the original scenarios of Kahneman et al., the firm cuts pay under scenario 1, and increases wages by less than inflation under scenario 2. Since unilateral wage cuts are not permitted in Sweden, we chose a somewhat different phrasing. Thus, our firm proposes a certain wage change, and we then simply asked the respondent to assess "...how your employees would find this proposal". Our respondents were asked to rate their employees' reactions to the two scenarios according to the following five alternatives: entirely unacceptable, highly unacceptable, hardly acceptable, acceptable subject to qualifications, and acceptable. To arrive at the results of the main text, we aggregated the three former under "not acceptable", and the two latter under "acceptable."
} 
Scenario 2 (861 respondents). Assume hypothetically that your enterprise is making a small surplus. Inflation is $10 \%$ percent, and unemployment is high. There are many job seekers applying for a job at your unit. Under these circumstances you decide to propose a pay increase of only $5 \%$. How do you think that your employees would find this proposal? (Question 13b.)
Acceptable
$49.6 \%$
Not acceptable $\quad 50.4 \%$

Although both scenarios have identical real implications, many managers responded that their employees would find it easier to accept a reduction in real wages that occurs through inflation, than through a nominal pay cut. These results are strikingly similar to those reported by Kahneman, Knetsch, and Thaler (1986). In their telephone survey of randomly selected residents of Toronto and Vancouver, 62 percent indicated that it was "unfair" to cut nominal pay under the circumstances of scenario 1, while only 22 percent thought the same about the five percent pay rise in scenario 2 . Judging from these responses 40 percent (62-22) of the respondents of Kahneman et al. (1986) were subject to money illusion, while 43.9 percent (94.3-50.4) of our respondents indicated the same.

It was probably difficult for our managers to come up with well-founded answers to our hypothetical scenarios. Yet, we find it interesting that our professional wage negotiators seem to be as convinced that money illusion is an important phenomenon in the labor market as the student- and laymen-populations that participate in surveys and laboratory experiments. Shafir, Diamond and Tversky (1997) report a range of survey evidence with a bearing on money illusion. Their data was gathered from survey questions asked to people in shopping malls and an airport. They also report evidence from surveys of undergraduate students at Princeton University. Fehr and Tyran (2001) report interesting experimental results on money illusion; subjects were undergraduates at the University of Zurich.

\section{Unemployment stigma, job security and hiring costs}

So far we have dealt with questions of an immediate relevance for students of wage rigidity. But our survey also includes questions that are less directly related to wage rigidity. In this and subsequent sections, we summarize this evidence, which deals with various issues in the economics of personnel. 


\section{$6 A$. Is there a stigma from long-term unemployment?}

It is a common argument that firms view unemployed job seekers as less productive.

Such a stigma may arise for a number of reasons. The skills of the unemployed can be expected to deteriorate over time, firms may suspect that unemployed workers are "lemons" that have been discarded by other firms, etc. These mechanisms may generate unemployment persistence in the wake of a macroeconomic shock; see Blanchard and Diamond (1994) and Eriksson and Gottfries (2000). To examine whether there is a negative reputation effect from unemployment, we asked:

How long time must a person have been unemployed before you consider $\mathrm{him} / \mathrm{her}$ to be less suitable for a job, in spite of the fact that the person in other respects appears to satisfy all requirements? (Question 14a.)

While 37.5 percent of our respondents indicated that unemployment was of no concern, 62.5 percent indicated that there was a negative reputation effect from unemployment spells of varying lengths. We conclude that unemployment stigma is a significant phenomenon. Bewley (1999, chapter 15) reaches a somewhat different conclusion. Though some of his managers indicated that unemployment was a bad sign, the dominant view appears to have been that unemployment was an unimportant consideration. Below, we will analyze to what extent strict job protection in Sweden can explain why the bias against the (long-term) unemployed appears to be more severe in our survey. ${ }^{28}$

Labor market training was a main strategy for combating unemployment during the Swedish crisis of the 1990s. It is not obvious how training affects the stigma from unemployment. If employers expect that training programs upgrade the skills of participants, there will be a weaker stigma. If employers expect that lowability workers get systematically sorted into these programs, there will be a greater stigma. To compare the possible reputation effects from participation in training with the reputation effects from unemployment, we asked:

\footnotetext{
${ }^{28}$ Which explanatory variables are correlated with the stigma from unemployment? We conducted our standard logit analysis (not shown), but found few significant correlations. We found no support for the idea that the stigma from unemployment ought to increase with the skill level of the workplace (the coefficient on UNIVERSITY is not statistically significant in our specifications). In a survey of British managers, Meager and Metcalf (1987) conclude that the bias against the long-term unemployed increases with the skill level of the job to be filled. The only near-robust finding is that managers with a large share of foreign employees are less likely to bother about the unemployment record of job applicants.
} 
Assume that a person has alternated between unemployment and participation in a training program for some time. How long time must the person have been in this situation before you consider him/her to be less suitable for a job, in spite of the fact that the person in other respects appears to satisfy all requirements? (Question 14b.)

The responses suggest that participation in a training program tends to mitigate the stigma from unemployment. ${ }^{29}$ Figure 2 merges the responses to Questions 14a-b. Comparing the distributions, the one showing the response to Question $14 \mathrm{~b}$ has more mass to the right, which suggests that training tends to prolong the time required for the stigma from unemployment to develop. A formal statistical test gives the same message. Of the 866 respondents who replied to both Question 14a and Question 14b, 40 indicated that there was less stigma from regular unemployment than from unemployment/training, 232 that there was less stigma from unemployment/training, and 594 that the states conveyed the same stigma. To obtain a $p$-value for this outcome, consider a binomial distribution with $p=.5$ and $N=272$; i.e. a distribution with the same probability that a respondent picks either of two alternatives. Our 40 “yeas" and 232 "nays" have been drawn from this distribution with $p-v a l u e<.0001$.

\section{B. Job security and hiring costs}

Several authors have studied how job protection affects firms' decisions on hirings and firings, and the implications for aggregate unemployment dynamics. ${ }^{30}$ Our survey included questions that tried to shed light on these arguments. Because we have a lot of information about worker-firm characteristics, we were curious to see whether we could identify factors that weakened or strengthened the link between job protection and firms' hiring decisions. We asked how job security affected the screening of job applicants (Question 4a). A majority (54 percent) indicated that job protection to a

\footnotetext{
${ }^{29}$ The written comments of some respondents suggest that our questions on the stigma from unemployment/training were phrased in too general terms. One respondent indicated that the unemployment history of a job applicant must be judged against the unemployment situation in the region of residence of the job applicant. A couple of other respondents indicated that any negative signaling effects from labor market training depend crucially on the type of training program.

${ }^{30}$ See Bentolila and Bertola (1990) and Bertola (1990). For a recent overview of the literature, see Bertola (1999). For aggregate evidence on the effects of job protection on unemployment dynamics, see Blanchard and Wolfers (1999). Swedish job security provides employees with far reaching protection against unfair dismissal, advance notice when laid off, layoffs according to a strict seniority principle, and severance pay. The only legal grounds for dismissal are redundancies and severe
} 
"very great" or "fairly great" extent boosted their screening effort. This clear-cut response appears to vindicate the assumption of the theoretical models that legal obstacles to firings increase the costs of hirings.

To avoid the commitments associated with a permanent employment contract, firms face an incentive to adjust to a business upturn by overtime work rather than by new hirings. This is also one of the mechanisms that may generate unemployment persistence after an adverse macroeconomic shock, see e.g. Bertola (1999). Other ways of avoiding the commitment of a permanent contract is to exploit the flexible arrangements that are permitted by law (trial employment and hirings from temporary work agencies). When asked about these mechanisms (Questions $4 \mathrm{~b}$ and $4 \mathrm{c}$ ), 38 percent of all managers indicated that job protection to a "very great" or "fairly great" extent boosted their use of overtime work (at the expense of new hirings), and 32.8 percent indicated that job protection gave the same boost to their use of temporary contracts.

Table 17 shows our analysis of how job protection affects managers' choice between new hirings and overtime during a business upturn. The coefficient on LOGSIZE is negative and significant in all columns, indicating that job protection has a more adverse impact on hirings in smaller units. One way of rationalizing this robust correlation is by noting that fixed hiring and firing costs created by job protection ought to be of greater concern for smaller units. ${ }^{31}$ Furthermore, the coefficient on PUBLIC is negative in columns 1 and 3 (with t-ratios of about 5 and 6). It appears that job protection is less of a hindrance to new hires among public sector units.

\section{C. Job security and the stigma from long-term unemployment}

Kugler and Saint-Paul (2000) argue that long-term unemployment is associated with a more severe stigma in an environment where job protection is strict. Since job protection can be expected to make firms more sensitive to the risk of hiring a "lemon", and since long-term unemployment can be interpreted as a signal of lowproductivity, job protection gives firms an incentive to hire employed job seekers instead of unemployed ones.

personal misconduct. Turning out to have a lower ability than the firm expected at the time of hiring is no legal ground for firing an employee.

${ }^{31}$ It is of some interest to note that we also found that respondents in small units had a significantly more positive appreciation of the labor turnover version of the insider-outsider model; see footnote 24. 
As a simple test of this explanation we computed the correlations between our questions on job security (Questions $4 \mathrm{a}-\mathrm{c}$ ) and those on the stigma from long term unemployment/training (Questions 14a-b). The responses to Questions 4a-c were given on a scale from 1 to 4 , with 4 indicating that job protection was an unimportant consideration. We coded the responses to Questions 14a-b on an ordinal scale from 1 to 6 , with 6 indicating the weakest form of stigma. The Spearman rank correlations between the responses are shown in Table 18. All rank correlations are positive and highly significant. In line with the theoretical prediction, managers who indicate that job protection is an important consideration are also the ones who are the most likely to view long term unemployment as a negative factor in the recruitment process.

\section{Motivation}

\section{A. How to motivate}

What tools do firms use to motivate their employees? We asked respondents to indicate to what extent they relied on the following (see Questions 9a-9d): (i) supervision and monitoring, (ii) career ladders, (iii) performance-related pay, and (iv) measures to promote good management-worker relations. In asking about the latter we provided examples of the techniques that according to management texts could be used to stimulate good management-worker relations, like making the job interesting, delegating authority and communicating the goals of the firm.

There is an obvious risk that respondents' choice between "good managementworker relations" and e.g. "supervision and monitoring" is biased by a framing effect; after all, "good relations" sounds so much nicer than monitoring! Even so, we find it noteworthy that such a large majority ranked good relations as a more important motivational tool than all the standard tools discussed in the economics literature, see Table 19. For example, in all sectors 63.9 percent indicated that they relied on good management-worker relations to a great or fairly great extent, while only 15 percent indicated the same about supervision and monitoring. ${ }^{32}$ Respondents in unskilled service units relied on supervision and monitoring to a greater extent. Still, only 27.9

\footnotetext{
${ }^{32}$ Agell and Lundborg $(1995,2002)$, Bewley (1999) and Campbell and Kamlani (1997) are other studies reporting that human resource managers often deny the relevance of the motivational tools assumed in the canonical shirking model of Shapiro and Stiglitz (1984).
} 
percent of the respondents in this sector indicated that supervision and monitoring was used to a great or fairly great extent, while almost 70 percent indicated the same about good relations. Respondents in skilled services pointed to the importance of career ladders, a device that plays a key role in theories of tournaments and work-life incentives, see Lazear (1995).

Table 20 shows our analysis of the determinants of firms' choice of motivational technique. In column 1 the coefficient on UNIVERSITY is significant at the one percent level, which suggests that units with a highly educated workforce are significantly less prone to use "supervision and monitoring". In columns 2, 3 and 4 the coefficients on BASICSCHOOL are negative and significant (but only at the ten percent level in column 2). It thus appears that units with a lowly educated workforce make less intensive use of (i) career tracks, (ii) performance-related pay, and (iii) measures to promote good relations. There is also a highly significant size effect; the willingness to use career ladders and performance related pay increases with LOGSIZE. The coefficients on PUBLIC are negatively significant in columns 2 and 3 , suggesting that public units pay less attention to explicit incentive mechanisms. Finally, the willingness to design career ladders decreases with FEMALE, and increases with MULTIUNIT. Of the results not shown, the most interesting one is that the coefficient on UNIONDENSITY is not statistically significant in any of the regressions. Thus, we find no evidence that firms with a large union presence find it more difficult to monitor work effort, and to use career ladders and performance related pay.

To examine in more detail firm's choice of motivational technique we computed the Spearman rank correlations between the answers to Questions 9a-d. The most noteworthy finding was that there appears to be a positive association between firms' use of explicit pecuniary incentives on the one hand, and the use of soft incentives (promotion of good relations) on the other. The Spearman correlation between the answers to questions $9 \mathrm{~b}$ (career tracks) and 9d (good relations) was 0.30 , and the correlation between 9c (performance-related pay) and 9d was 0.14 ( $p$-value $<.0001$ for both correlations). One way of thinking about these correlations is with reference to recent experimental results suggesting that monetary reward schemes tend to crowd out voluntary cooperation and "intrinsic motivation", see Fehr and Gächter (2002) and the references cited therein. To the extent that 
explicit incentives have a negative side effect on intrinsic motivation, firms that rely on explicit incentives to a great extent may have much to gain from also making extensive use of soft incentives that make employees more loyal to the firm.

\section{B. Is competition good for productivity?}

Is competition among employees good or bad for productivity? Economic theory offers no clear guidance. Tournament theory predicts that competition for wages and career slots encourages work effort, see Lazear and Rosen (1981). But there are also models suggesting that competition discourages cooperation, and provides workers with incentives to sabotage the effort of their coworkers, see Lazear (1989). We briefly described these possibilities, and then asked the following:

In your opinion, how does (or would) keen competition between employees affect work motivation at your workplace? (Question 7.)

As can be seen from Figure 3, respondents were sharply divided on the net benefits from keen competition between workers, with 37 percent responding that competition was largely detrimental, 44.8 percent that it was largely beneficial, and the remaining 18.2 percent indicating that the costs about balanced the benefits. In a follow-up question we asked whether large wage differentials were beneficial or detrimental for work motivation. Again, we obtained a bimodal response distribution: 36.1 percent thought that large wage differentials were detrimental, 50.9 percent that they were beneficial and 13 percent that the negative and positive effects cancelled out.

To analyze the determinants of respondents' attitude towards competition and wage differentials, we proceeded as follows. There were five response options to Questions 7 and 8, and we coded them as 1, 2, 3, etc. We then estimated a set of ordered logit models, where we used our benchmark regressors from Table 4 . These regressions indicate that many of the variables that we a priori thought to be of importance for managers' assessment of the motivational pros and cons of competition/wage differentials had no explanatory power. Thus, neither of sectoral affiliation, union density and educational characteristics played a significant role.

However, one regressor did turn out as we expected. In the previous section we showed that larger firms make more frequent use of explicit incentives, and in Table 21 we show that size also appears to be positively correlated with managers' 
attitudes to competition/wage differentials. Row 1 shows that there is a positive Spearman correlation between LOGSIZE and managers' appreciation of the benefits from competition, and between LOGSIZE and the appreciation of the benefits from large wage differentials. Though the former correlation is small, the latter is large and highly significant. Rows 2-4 show the estimated coefficient on LOGSIZE in our multivariate regressions. The correlation between LOGSIZE and respondents' appreciation of the benefits from large wage differentials is positive and highly significant, and it survives changes in the set of conditioning variables (rows 3 and 4). Our evidence on the correlation between LOGSIZE and respondents' appreciation of the benefits from competition is weaker. In rows 2 and 4 LOGSIZE is significant at the ten percent level. But in our stepwise regression in row 3 LOGSIZE does not belong in the final set of explanatory variables.

One way of interpreting this evidence is with reference to Lazear (1989), who shows that the benefits from creating a competitive work environment - where relative rewards play an important role - depend on firms' ability to match workers with appropriate personalities. To the extent that it is easier to create such matches in a large organization, respondents in large firms ought to have a more positive attitude towards competition, and towards incentive schemes based on relative wages. In the related model of Priks (2002) effort-based pay provides employees with an incentive to increase output, but it also provides employees with an incentive to engage in costly rent-seeking within the firm. Under certain assumptions the former effect will dominate the latter one for large firms, while the opposite will be true for small firms. In equilibrium we would then expect to see effort-based pay in large firms, and egalitarian pay schemes in small firms.

\section{Gender and models of work and pay}

A large literature analyzes gender differentials in the labor market; see Altonji and Blank (1999) for an overview. Though our survey was not primarily intended as a contribution to this literature, our econometric analysis has revealed certain regularities that we have not seen documented in previous survey-research. This section explores the robustness of these findings. 
Table 22 reports our sensitivity analysis. In Section 5C (Table 9) we noted that firms with a large share of female employees were less likely to believe that employees who were unhappy with their pay would reciprocate by reducing effort, and column 1 examines the robustness of this finding. Row 1 reproduces the highly significant coefficient on FEMALE from Table 9. In row 2 we show that the univariate Spearman correlation between FEMALE and the response variable is in fact small, and not significantly different from zero. Some exploration shows that this result is entirely due to the omission of industry dummies. Because the share of female workers differs systematically between sectors (see Table 3), the univariate correlation coefficient picks up all confounding influences due to omitted sectorspecific effects. In row 3 we see that the coefficient on FEMALE becomes highly significant as we reintroduce controls for sectoral affiliation at the two-digit level. In row 4 we show that FEMALE drops out of the final specification of our stepwise regression. This is due to the fact that the controls for industrial affiliation were not jointly significant at the five percent level and thus excluded. However, if we instead exclude variables not significant at the ten percent level FEMALE would be in the final model with $p$-value $=0.001$. Finally, rows 5 and 6 show that the coefficient on FEMALE remains significant at the one percent level as we estimate ordered logit models, which exploit the full variation in our data.

In tables 14 and 15 we showed that both profits/ability to pay and external wage relativities appeared to play a lesser role in the local wage bargain in units with a large share of female employees. Columns 2 and 3 show that these results survive all our sensitivity tests. Finally, column 4 examines how gender affects firms' willingness to design career ladders. The coefficient on FEMALE is negative and significant in all specifications where we use the industry dummies of Table 4 . In the specifications with two-digit dummies the coefficient remains negative, but it is not significant at conventional levels.

In our sample firms with a large share of female employees have lower earnings, an effect which survives even as we introduce a range of controls for sectoral affiliation and worker-firm characteristics, see Table 5. The regularities that we have documented in this section suggest that part of the reason may derive from innate psychological and sociological differences between men and women. Taken at face value the results of Table 22 seem to imply that: 
(i) Women are less aggressive wage bargainers, caring less about external wages and profits/ability to pay. Alternatively, we may think of women as having a weaker position in the local wage bargain.

(ii) Women feel greater loyalty to their employer, in the sense that they are less prone to counter a perceived wage inequity with a retaliatory effort reduction.

(iii) Firms perceive a lesser need to create explicit incentive schemes (like career ladders) in a work-environment dominated by female employees.

The speculative nature of these conclusions need not be emphasized. ${ }^{33}$ In the future we believe that specially designed surveys could be used to sort out whether men and women have different attitudes towards monetary incentives, reciprocity, etc. One way of testing for such gender effects would be to send out the same questionnaire (containing identical questions about motivation, reciprocity, wage norms, etc) to a sample of men and women holding similar jobs at the same firm.

\section{Concluding remarks}

Can a student of wage rigidity and wage policy learn anything useful by asking questions to those in charge of wage bargaining and personnel relations? In recent years some economists have answered this question in the affirmative. This paper is a contribution to this literature. Unlike previous studies, we use a randomized sampling design, which provides us with a representative coverage of firms in different sectors, and in different size categories, including 300 units with less than 20 employees. Because we have detailed information about worker-firm characteristics, we can probe deeper than the preceding literature in identifying behavioral regularities.

We believe that the following concluding observations are in order. First, from the point of view of macroeconomic research on wage rigidity our most important finding is probably that we corroborate the results from previous, less representative surveys. Real world managers appear to believe that their workers are subject to money illusion, that work morale matters for performance, and that employees who feel dissatisfied with their pay normally reduce effort. Moreover, these findings are in more or less complete agreement with recent evidence from experimental labor

\footnotetext{
${ }^{33}$ To the best of our knowledge, no other survey has explored the role of gender in shaping attitudes towards incentives and motivation. Recent experimental studies indicating that men and women exhibit
} 
markets. As noted by Howitt (2002) in his review of Bewley (1999), many of these insights from surveys and experiments can be explained along the lines of reciprocitytheory, developed by e.g. Rabin (1993) and others.

Second, we have analyzed how wage policy and wage rigidity differ between segments of the labor market. Our most consistent finding is probably that an astonishing number of mechanisms appear to differ significantly between large and small organizations. Small organizations rely less on pecuniary incentives, and managers in these firms appear to have a more hostile attitude towards incentive schemes based on competition and relative wages. Larger organizations appear to be more vulnerable to the mechanisms of efficiency wages, and managers in large organizations appear to have more reason to fear that poor work morale impacts badly on work performance.

Third, we have reported evidence that mechanisms of wage rigidity tend to complement each other, a possibility that is rarely acknowledged in models of wage rigidity. As noted by Summers (1988), models that simultaneously allow for e.g. bargaining and efficiency wages/relative wages generate more persistent rigidity than models that deal with one complication at a time. We are not aware of any other study that has empirically documented these interactions.

Fourth, we have shown that despite several years of very low inflation and high unemployment the incidence of nominal wage cuts in Sweden has been exceptionally low. In this context, it should be noted that previous macroeconometric research, based on data from the 1970s and 1980s, has indicated that Swedish real wages are in fact quite responsive to the unemployment level, see Calmfors and Forslund (1990) and Layard, Nickell and Jackman (1991). However, these aggregate econometric studies rely on data from decades of high inflation, when adjustments of real wages could occur simply by letting wage inflation fall behind price inflation. ${ }^{34}$ The findings of this paper are certainly consistent with the view, often attributed to Tobin (1972), that the rigidity of real wages can be expected to increase significantly as inflation falls to zero.

different degrees of "selfishness" or "generosity" include e.g. Eckel and Grossman (1998) and Dufwenberg and Muren (2002).

${ }^{34}$ In a recent aggregate econometric study, Forslund and Kolm (2000) conclude that real wages in Sweden show little responsiveness to unemployment. Forslund and Kolm include data from the 1990s, when Swedish unemployment has been high, and inflation low. 
Though we believe that our statistical design represents a considerable improvement over the important preceding literature, a final disclaimer is in order. Since there are a limited number of questions that can be added to a single survey we focus on a fairly narrow range of issues. We emphasize mechanisms of wage rigidity that operate at the local level, and we have more questions about endogenous sources of wage rigidity than about legal institutions. Surveys that specifically deal with e.g. legal institutions seem like a useful complement to the present study. However, to fully explore the effects of country-specific institutions it appears that a broader survey design is called for, like sending out the same questionnaire to firms in countries with different institutions. 


\section{Appendix 1: Analysis of non-response bias}

To assess the magnitude of the potential non-response bias we studied how the replies of late responders (i.e. those returning the questionnaire after one or more reminders) related to the replies of those responding immediately. We compared the replies on questions $4 \mathrm{a}-14 \mathrm{c}$ of the questionnaire (26 questions in all) of the 282 late responders with the replies of the 603 immediate responders. According to the Wilcoxon-MannWhitney test of shift in location between two populations there were significant differences $(p<0.05)$ in the replies to three out of 26 questions. Late responders were more inclined to choose an alternative indicating little acceptance of the statements in questions $4 \mathrm{~b}$ and $12 \mathrm{a}$, and to choose an alternative indicating a lesser stigma from long-term unemployment (question 14a).

We next make the assumption that non-responders would have answered questions $4 \mathrm{~b}, 12 \mathrm{a}$ and $14 \mathrm{a}$ in the same way as the late responders. More precisely, for each of our 12 strata we assumed that non-responders would have answered these questions in exactly the same way as did the late responders. By adding these hypothetical replies of the non-responders to the actual ones we can then obtain a predicted response distribution for the full sample. By comparing this predicted distribution with the actual one, we obtain an estimate of the potential non-response bias.

When we perform this exercise for question $4 \mathrm{~b}$, (does protection reduce hirings?) the percentage of respondents choosing alternatives $(1,2,3,4)$ changes from $(15.9,22.2,33.5,28.4)$ to $(14.9,23.0,34.1,28.0)$. For question 12a (does Keynes's relative wage theory describe relevant mechanism?), the percentage of respondents choosing alternatives $(1,2,3,4,5)$ changes from $(10.8,37.7,28.3,10.4,12.8)$ to $(10.2,36.0,28.9,11.0,13.9)$. Finally, for question 14 a (how long spell of unemployment is required before there is a stigma from unemployment?) the percentage of respondents choosing alternatives $1-6$ changes from $(37.5,5.1,16.5$, $20.5,5.1,15.3)$ to $(39.4,5.2,16.0,20.4,5.0,14.0)$.

Based on this standard method of analyzing non-response bias, we conclude that the potential bias is quite small in our survey. The small difference between hypothetical and actual responses reflects two circumstances. First, the responses of late responders do not differ much from those of the immediate responders. Second, the percentage of non-response (24.9\%) in our survey is in fact quite low. 


\section{Appendix 2: Covering letter and questionnaire}

\section{Survey about pay and unemployment}

The Institute for Labour Market Policy Evaluation (IFAU) has asked Statistics Sweden to conduct a survey about pay setting and causes of unemployment. The questionnaire is distributed to a sample of 1200 firms/organizations with at least five employees.

\section{Purpose of the survey}

The purpose of the survey is to provide important information about how the process of pay determination affects unemployment. What are the reasons for wage rigidity? Is wage rigidity a cause of persistent unemployment? Does the institutions of wage setting prevent the unemployed from re-entering the labour market? These are some of the questions researchers want to learn more about. The survey also contains questions on the effects of legislation, wage bargaining, personnel policy, etc.

\section{The questions}

The survey is primarily directed at central decision-makers in various types of firms and organizations. We would greatly appreciate your contribution to the research on the reasons for unemployment by responding to the survey. The greatest benefit will be derived if the human resource manager or someone with corresponding experience of personnel policy and pay bargaining answers the survey. To avoid burdening the survey with information that exists in other sources of statistics, the answers will be supplemented with information on responding firms' employment structure from Statistic Sweden's Employment Register.

\section{Confidentiality}

The answers to the survey will be treated confidentially and will solely be used for research purposes. When the investigation is complete, the material will be handed over to IFAU in a non-traceable format. All the information we gather is protected by the Official Confidentiality Act, Chapter 9, Paragraph 4. The survey design and questionnaire have been approved by the Board of Swedish Industry and Commerce for Better Regulation (Näringslivets nämnd för regelgranskning).

\section{Questions about the survey}

Questions about the survey, or about the project, are answered by the project manager: Professor Jonas Agell, Department of Economics, Uppsala University, phone: +46 18 471 1104. You may also contact Agneta Sandqvist at Statistics Sweden, phone: +46 19 176027; e-mail: agneta.sandqvist@scb.se.

Please answer the questions and return the survey to Statistics Sweden in the enclosed envelope by April 6, 1999. Thank you in advance for your participation.

Sincerely,

Jonas Agell

Professor

Uppsala University
Agneta Sandqvist

Head of Survey Division

Statistics Sweden 
1a Have wages (regular hourly wage, monthly salary, piece wage, etc.) been reduced at any time at your workplace during the crisis years of the 1990s?

$1 \square$ Yes

$2 \square$ No $\rightarrow$ Go to question 2a

1b What percentage of your staff was affected by the wage reduction?

\begin{tabular}{|c|}
\hline $0-2 \%$ \\
\hline $3-4 \%$ \\
\hline $5-6 \%$ \\
\hline $7-10 \%$ \\
\hline $11-20 \%$ \\
\hline $21-30 \%$ \\
\hline $31-40 \%$ \\
\hline $41-50 \%$ \\
\hline $51-70 \%$ \\
\hline $71-100 \%$ \\
\hline
\end{tabular}

2a What percentage of your staff belongs to a trade union?

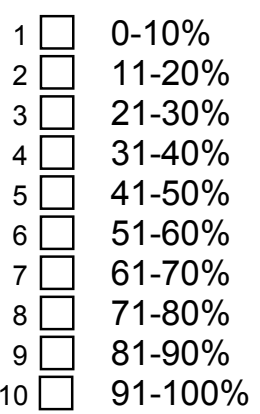

2b What percentage of your staff is covered by some form of profit-sharing system, bonus system, or other system for sharing company profits.

\begin{tabular}{|c|c|}
\hline 1 & $0-10 \%$ \\
\hline & $11-20 \%$ \\
\hline & $21-30 \%$ \\
\hline & $31-40 \%$ \\
\hline & $41-50 \%$ \\
\hline & $51-60 \%$ \\
\hline & $61-70 \%$ \\
\hline & $71-80 \%$ \\
\hline & $81-90 \%$ \\
\hline & $91-100 \%$ \\
\hline
\end{tabular}


2c What percentage of your staff is covered by some form of piece-rate system.

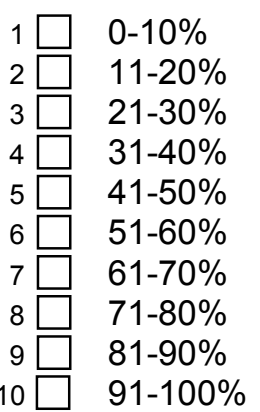

2d What percentage of your staff has a permanent employment contract?

\begin{tabular}{|c|c|}
\hline & $0-10 \%$ \\
\hline & $11-20 \%$ \\
\hline 3 & $21-30 \%$ \\
\hline 4 & $31-40 \%$ \\
\hline & $41-50 \%$ \\
\hline 6 & $51-60 \%$ \\
\hline & $61-70 \%$ \\
\hline & $71-80 \%$ \\
\hline & $81-90 \%$ \\
\hline & $91-100 \%$ \\
\hline
\end{tabular}

2e For which of the questions $1 \mathrm{~b}-2 \mathrm{~d}$ did you make a rough estimate? Check those questions for which you made a rough estimate
$1 \square$ Question 1b
$2 \square$ Question 2a
$3 \square$ Question 2b
$4 \square$ Question 2c
$5 \square$ Question 2d

3a Does it happen that your workplace is approached by job seekers who offer to work under conditions that are inferior (lower pay, less convenient hours, poorer work environment, etc.) to those you normally offer new employees with corresponding qualifications?
$1 \square$ Yes, frequently
$2 \square$ Yes, occasionally
$3 \square$ Yes, but only seldom
$4 \square$ No, never $\rightarrow$ Go to question $4 a$ 
3b Have any of these individuals been employed under such inferior conditions?

$1 \square$
$2 \quad \square$
$3 \quad \square$
$4 \quad \square$

Yes, most of them $\rightarrow$ Go to question $4 a$

Yes, some of them $\rightarrow$ Go to question $4 a$

Yes, but only seldom

$4 \square$ No, never

To be answered by those persons who selected alternative 3 or 4 to question $3 b$

3c Why are these individuals seldom or never employed?

a The union opposes it

b Violation of firm's personnel policy

c No vacancies

d Laws and collective bargaining agreements prevent it

e Creates conflict among employees

f Individuals who offer to work under

No sig- Little sig- Some sig- Great sig- Decisive nificance nficance nificance nificance factor inferior conditions are less productive

g Other explanation

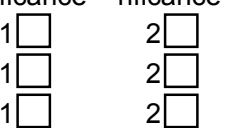

$3 \square$
$3 \square$
$3 \square$

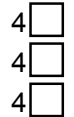

$5 \square$

$2 \square$

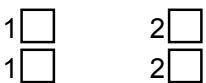

$3 \square$

$4 \square$

$5 \square$

1

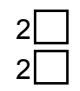

$3 \square$

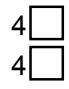

$5 \square$
$5 \square$

4a To what extent do the obligations associated with the Employment Security Act (LAS) induce you to make a more thorough review of job applicants' qualifications than would else be the case?
$1 \square \quad$ To a very great extent
$2 \square$ To a fairly great extent
$3 \square$ To some extent
$4 \square \quad$ None at all

4b To what extent do the obligations associated with the Employment Security Act make you more prone to adjust to a business upturn by requiring the current staff to work overtime rather than by hiring new personnel?

\footnotetext{
$1 \square \quad$ To a very great extent

$2 \square \quad$ To a fairly great extent

$3 \square$ To some extent

$4 \square \quad$ None at all
} 
4c To what extent do the obligations associated with the Employment Security Act induce you to offer flexible, short-term contracts in the form of trial employment, use of personnel from temporary hiring agencies, etc?

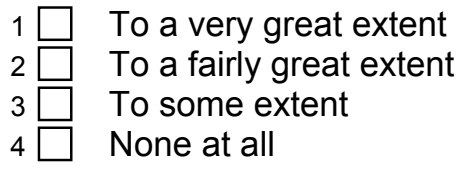

5a To what extent can you evaluate whether a specific employee performs satisfactorily on the job?

$1 \square \quad$ To a very great extent

$2 \square$ To a fairly great extent

$3 \square$ To some extent

$4 \square \quad$ None at all

5b To what extent can you, where appropriate, evaluate whether a group of employees (e.g. a team, division, project group, etc) performs satisfactorily on the job?
$1 \square \quad$ To a very great extent
$2 \square$ To a fairly great extent
$3 \square$ To some extent
$4 \square \quad$ None at all
$5 \square \quad$ Not applicable

6a How do you think that the work effort of your employees would be affected if there was less unemployment in the region?
$1 \square$ Greatly deteriorate
$2 \square$ Deteriorate somewhat
$3 \square \quad$ No change
$4 \square \quad$ Improve somewhat
$5 \square$ Greatly improve

6b How do you think that the work effort of your employees would be affected if wages/salaries increased in comparable companies or organizations, but stayed the same at your unit?
$1 \square \quad$ Greatly deteriorate
$2 \square$ Deteriorate somewhat
$3 \square \quad$ No change
$4 \square$ Improve somewhat
$5 \square$ Greatly improve 
6c How do you think that the work effort of your employees would be affected if unemployment benefits were increased?
$1 \square$ Greatly deteriorate
$2 \square$ Deteriorate somewhat
$3 \square \quad$ No change
$4 \square$ Improve somewhat
$5 \square$ Greatly improve

According to some theories, keen competition between employees for salaries and career opportunities will stimulate people to work harder, which is beneficial to the workplace. According to other theories, keen competition between employees results in a poor climate of cooperation, which is detrimental to the workplace.

7 In your opinion, how does (or would) keen competition between employees affect work motivation at your workplace?

$1 \square$ Solely negatively

$2 \square \quad$ Both negatively and positively, but mostly negatively

$3 \square$ Neither negatively nor positively

$4 \square$ Both negatively and positively, but mostly positively

$5 \square$ Solely positively

8 Differences in pay among employees can have different effects on work motivation. In your opinion, how do (or would) large pay differentials affect work motivation at your workplace?

$1 \square$ Solely negatively

$2 \square$ Both negatively and positively, but mostly negatively

$3 \square \quad$ Neither negatively nor positively

$4 \square$ Both negatively and positively, but mostly positively

$5 \square$ Solely positively

How can one promote employee motivation? Indicate to what extent you apply the following measures.

9a To what extent do you supervise and monitor the work performance of your employees?

\footnotetext{
$1 \square \quad$ To a very great extent

$2 \square$ To a fairly great extent

$3 \square \quad$ To some extent

$4 \square \quad$ To a very little extent

$5 \square \quad$ Not at all
} 
9b To what extent do you establish career tracks, which give able employees the opportunity to qualify for promotion?
$1 \square \quad$ To a very great extent
$2 \square$ To a fairly great extent
$3 \square$ To some extent
$4 \square$ To a very little extent
$5 \square \quad$ Not at all

9c To what extent do you pay wages/salaries that are linked to performance?
$1 \square \quad$ To a very great extent
$2 \square \quad$ To a fairly great extent
$3 \square$ To some extent
$4 \square$ To very little extent
$5 \square \quad$ Not at all

9d To what extent do you try to promote good management-worker relationships (e.g. by creating interesting work-assignments, delegating decision-making, formulating transparent objectives for your activities, etc)?
$1 \square \quad$ To a very great extent
$2 \square$ To a fairly great extent
$3 \square$ To some extent
$4 \square$ To very little extent
$5 \square$ Not at all

10a During pay negotiations, how common is it that your employees (or their union representatives) compare their pay with that of other employees at your own workplace?
$1 \square$ Always
$2 \square$ Frequently
$3 \square$ Sometimes
$4 \square$ Infrequently
$5 \square$ Never

10b During pay negotiations, how common is it that your employees (or their union representatives) compare their pay with that of employees at other workplaces?
$1 \square$ Always
$2 \square$ Frequently
$3 \square$ Sometimes
$4 \square$ Infrequently
$5 \square$ Never 
10c How common is it that your employees (or their union representatives) require wage hikes because of high profits, or high ability to pay, in your firm/organization?

$\begin{array}{ll}1 \square & \text { Always } \\ 2 \square & \text { Frequently } \\ 3 \square & \text { Sometimes } \\ 4 \square & \text { Infrequently } \\ 5 \square & \text { Never }\end{array}$

11a In your opinion, do those of your employees who are dissatisfied with their pay normally reduce performance?
$1 \square$ Yes, definitely so
$2 \square$ Yes, to a great extent
$3 \square$ Yes, to some extent
$4 \square$ Yes, but only occasionally
$5 \square$ No, I do not think so

11b In your opinion, do those of your employees who are dissatisfied with their pay normally seek employment elsewhere?
$1 \square \quad$ Yes, definitely so
$2 \square$ Yes, to a great extent
$3 \square \quad$ Yes, to some extent
$4 \square$ Yes, but only occasionally
$5 \square \quad$ No, I do not think so

Below we present some economic theories and a few hypothetical examples that attempt to shed light on why wages/salaries seldom fall in spite of high unemployment.

12a Some researchers argue that the reason why wages seldom fall is that wage relativities might be altered. Employees try to protect their position in the wage hierarchy, and they resist wage cuts because they are afraid that they will fall behind other employees, at their own or other units.

To what extent does this explanation agree with your view/experience?

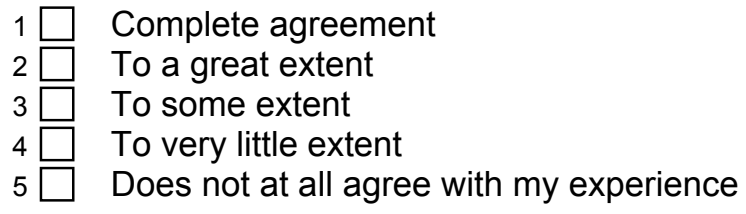


12b One theory to explain why wages may end up above the level that gives full employment is based on the notion that hirings and firings are costly to firms. These costs (for interviews, advertisements, training, redundancy payment, etc.) make firms eager to keep already employed workers. By pushing up wages, this situation is exploited by employees.

\section{To what extent does this explanation agree with your view/experience?}

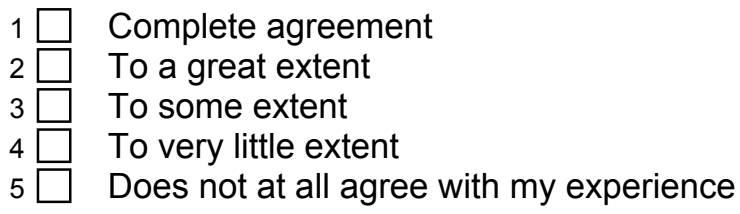

13a Assume hypothetically that your enterprise is making a small surplus. There is no inflation, and unemployment is high. There are many job seekers applying for a job at your unit. Under these circumstances you decide to propose a pay cut of 5\%.

\section{How do you think that your employees would find this proposal?}
$1 \square$ Completely unacceptable
$2 \square$ Highly unacceptable
$3 \square$ Hardly acceptable
$4 \square$ Acceptable with great hesitation
$5 \square$ Acceptable

13b Assume hypothetically that your enterprise is making a small surplus. Inflation is $10 \%$ percent, and unemployment is high. There are many job seekers applying for a job at your unit. Under these circumstances you decide to propose a pay increase of only $5 \%$.

\section{How do you think that your employees would find this proposal?}
$1 \square$ Completely unacceptable
$2 \square$ Highly unacceptable
$3 \square$ Hardly acceptable
$4 \square$ Acceptable with great hesitation
$5 \square$ Acceptable

14a How long time must a person have been unemployed before you consider $\mathrm{him} / \mathrm{her}$ to be less suitable for a job, in spite of the fact that the person in other respects appears to satisfy all requirements?
$1 \square$ Has no significance
$2 \square$ More than one month but less than six months
$3 \square$ More than six months but less than one year
$4 \square$ More than one year but less than 18 months
$5 \square$ More than 18 months but less than two years
$6 \square$ Two years or more 
14b Assume that a person has alternated between unemployment and participation in a training program for some time. How long time must the person have been in this situation before you consider him/her to be less suitable for a job, in spite of the fact that the person in other respects appears to satisfy all requirements?
$1 \square$ Has no significance
$2 \square \quad$ More than one month but less than six months
$3 \square$ More than six months but less than one year
$4 \square$ More than one year but less than 18 months
$5 \square$ More than 18 months but less than two years
$6 \square$ Two years or more

14c Assume that a person has alternated between unemployment and relief work for some time. How long time must the person have been in this situation before you consider him/her to be less suitable for a job, in spite of the fact that the person in other respects appears to satisfy all requirements?
$1 \square \quad$ Has no significance
$2 \square$ More than one month but less than six months
$3 \square$ More than six months but less than one year
$4 \square$ More than one year but less than 18 months
$5 \square$ More than 18 months but less than two years
$6 \square$ Two years or more

\section{Other comments}




\section{References}

Acemoglu, D. and J.-S. Pischke, 1999, "Beyond Becker: training in imperfect labour markets", Economic Journal 109, F112-F142.

Agell, J. 1999, "On the benefits from rigid labour markets: Norms, market failures, and social insurance", Economic Journal 109, F143-F164.

Agell, J. and P. Lundborg, 1995, "Theories of pay and unemployment: survey evidence from Swedish manufacturing firms", Scandinavian Journal of Economics 97, 295-307.

Agell, J. and P. Lundborg, 2002, "Survey evidence on wage rigidity and unemployment: Sweden in the 1990s", forthcoming, Scandinavian Journal of Economics.

Agell, S. A., 1994, "Swedish evidence on the efficiency wage hypothesis", Labour Economics 1, 129-150.

Akerlof, G., 1982, "Labor contracts as partial gift exchange”, Quarterly Journal of Economics 97, 543-569.

Akerlof, G., W. T. Dickens, and G. L. Perry, 1996, "The macroeconomics of low inflation”, Brookings Papers on Economic Activity, 1996:1.

Albaek, K., M. Arai, R. Asplund, E. Barth, and E. Strøjer Madsen, 1998, "Measuring wage effects of plant size", Labour Economics 5, 425-448.

Altonji, J. G. and R. M. Blank, "Race and gender in the labor market", in Handbook of Labor Economics, volume 3C (eds. O. Ashenfelter and D. Card), Elsevier: Amsterdam

Andrews, I. R. and M. M. Henry, 1963, "Management attitudes toward pay", Industrial Relations 3, 29-39.

Arai, M., 2001, "Wages, profits and capital intensity: evidence from matched workerfirm data", forthcoming, Journal of Labor Economics.

Baker, G., M. Gibbs and B. Holmstrom, 1994, "The wage policy of a firm", Quarterly Journal of Economics 109, 921-956.

Ball, L. and D. Romer, 1990, "Real rigidities and the nonneutrality of money", Review of Economic Studies 57, 183-203.

Beissinger, T. and C. Knoppik, 2001, "Downward nominal rigidity in West-German earnings, 1975-1995”, German Economic Review 2, 385-417.

Bentolila, S. and G. Bertola, 1990, "Firing costs and labor demand: How bad is Eurosclerosis?" Review of Economic Studies 57, 381-402.

Bertola, G., 1990, "Job security, employment and wages", European Economic Review 34, 851-886.

Bertola, G., 1999, "Microeconomic perspectives on aggregate labor markets", in Handbook of Labor Economics, volume 3C (eds. O. Ashenfelter and D. Card), Elsevier: Amsterdam

Bewley, T., 1995, “A depressed labor market as explained by participants”, American Economic Review 85 (Papers and Proceedings), 250-54.

Bewley, T., 1998, “Why not cut pay?” European Economic Review 42 (Papers and proceedings), 459-90.

Bewley, T., 1999, Why wages don't fall during a recession. Harvard University Press, Cambridge (Ma.) and London, England.

Blanchard, O. J. and P. Diamond, 1994, "Ranking, unemployment duration, and wages", Review of Economic Studies 61, 417-434. 
Blanchard, O. J. and J. Wolfers, 1999, "The role of shocks and institutions in the rise of European Unemployment: The aggregate evidence", The Economic Journal 110, C1-C33.

Blinder, A. and D. Choi, 1990, "A shred of evidence on theories of wage stickiness", Quarterly Journal of Economics 105, 1003-15.

Calmfors, L. and A. Forslund, 1990, "Wage formation in Sweden," in Wage formation and macroeconomic policy in the Nordic countries (ed. L. Calmfors), SNS Förlag and Oxford University Press: Stockholm.

Campbell, C. M. and K. S. Kamlani, 1997, "The reasons for wage rigidity: Evidence from a Survey of Firms", Quarterly Journal of Economics 112, 759-89.

Christofides, L. N. and T. Stengos, 2000, "Nominal wage rigidity: non-parametric tests based on union data for Canada", mimeo, Department of Economics, University of Guelph.

Drago, R. and J. S. Heywood, "Is worker behaviour consistent with efficiency wages?" Scottish Journal of Political Economy 39, 141-153.

Dufwenberg, M. and G. Kirchsteiger, 2000, "Reciprocity and wage undercutting", European Economic Review 44 (Papers and proceedings), 1069-1078.

Dufwenberg, M. and A. Muren, 2002, "Discrimination by gender and social distance", mimeo, Department of Economics, Stockholm University.

Eckel, C. C. and P. J. Grossman, 1998, "Are women less selfish than men? Evidence from dictator experiments", The Economic Journal 108, 726-735.

Ekberg, J., 2002, "Nominal wage rigidity on the Swedish labor market", Licentiate thesis, Stockholm School of Economics.

Eriksson, S. and N. Gottfries, 2000, "Ranking of job applicants, on-the-job search and persistent unemployment”, Working paper 2000:3, Department of Economics, Uppsala University.

Fehr, E. and A. Falk, 1999, "Wage rigidity in a competitive incomplete contract market", Journal of Political Economy 107, 106-134.

Fehr, E. and S. Gächter, 2000, "Fairness and retaliation: the economics of reciprocity", Journal of Economic Perspectives 14, 159-181.

Fehr, E. and S. Gächter, 2002, "Do incentive contracts undermine voluntary cooperation?", mimeo, University of Zurich and University of St. Gallen.

Fehr, E. and L. Goette, 2000, "Robustness and real consequences of nominal wage rigidity", CESifo Working Paper No. 335, Munich.

Fehr, E. and J.-R., Tyran, 2001, “Does Money Illusion Matter?” American Economic Review 91, 1239-1262.

Forslund, A. and A.-S. Kolm, 2000, "Active labour market policies and real-wage determination - Swedish evidence," IFAU Working Paper No. 2000:7, Uppsala.

Fortin, P., 1996, “ The great Canadian slump”, Canadian Journal of Economics 29, 761-787.

Fregert, K., 1994, Wage contracts, policy regimes and business cycles. A contractual history of Sweden 1908-1990. Lund Economic Studies, Lund.

Gächter, S. and E. Fehr, 2001, "Fairness in the labour market -- A survey of experimental results", in Surveys in Experimental Economics. Bargaining, Cooperation and Election Stock Markets (eds. Friedel Bolle and Marco Lehmann-Waffenschmidt). Physica Verlag.

Gottfries, N. and H. Horn, "Wage formation and the persistence of unemployment", The Economic Journal 97, 877-884. 
Hanes, C., 2000, "Nominal wage rigidity and industry characteristics in the downturns of 1893, 1929, and 1981", American Economic Review 90, 1432-1446.

Holden, S., 1994, "Wage bargaining and nominal rigidities", European Economic Review 38, 1021-1039.

Holden, S., 1998, "Wage drift and the relevance of centralized wage setting", Scandinavian Journal of Economics 100, 711-731.

Holden, S., 2001, "Does price stability exacerbate labour market rigidities in the EMU?" forthcoming, Empirica.

Holden, S., 2002, "The costs of price stability -- downward nominal wage rigidity in Europe", NBER Working Paper No. 8865, Boston.

Holmlund, B. and J. Zetterberg, 1991, "Insider effects in wage determination: evidence from 5 countries", European Economic Review 35, 1009-1034.

Howitt, P., 2002, "Looking inside the labor market: a review article", Journal of Economic Literature 40, 125-138.

Kahneman, D., J. L. Knetsch and R. Thaler, 1986, "Fairness as a constraint on profit seeking: entitlements in the market", American Economic Review 76, 728-741.

Kaufman, R., 1984, “On wage stickiness in Britain's competitive sector”, British Journal of Industrial Relations 22, 101-112.

Keynes, J. M.. 1936, The general theory of employment, interest and money. Macmillan, London.

Kugler, A. and G. Saint-Paul, 2000, "Hiring and firing costs, adverse selection, and long-term unemployment", Working Paper, Universitat Pompeu Fabra.

Layard, R., S. Nickell and R. Jackman, 1991, Unemployment. Oxford University Press, Oxford.

Lazear, E. P. and S. Rosen, 1981, "Rank-order tournaments as optimum labor contracts", Journal of Political Economy 89, 841-864.

Lazear, E. P., 1989, "Pay equality and industrial politics", Journal of Political Economy 97, 561-580.

Lazear, E. P., 1995, Personnel Economics. MIT Press, Cambridge (Ma.).

Lebow, D.E., R. E. Saks and B. A. Wilson, (1999), "Downward nominal wage rigidity. Evidence from the employment cost index", Working Paper, Board of Governors of the Federal Reserve System.

Levine, D., 1993, "Fairness, markets, and ability to pay: Evidence from compensation executives", American Economic Review 83, 1241-59.

Lindbeck, A., 1997, “The Swedish experiment," Journal of Economic Literature 35, 1273-1319.

Lindbeck, A. and D. J. Snower, 1988, The insider-outsider theory of employment and unemployment, MIT Press: Cambridge.

Lindbeck, A. and D. J. Snower, 2001, "Insiders versus outsiders", Journal of Economic Perspectives 15, 165-188.

McLaughlin, K. J., 1994, “Rigid wages?” Journal of Monetary Economics 34, 383414.

Meager, N. and H. Metcalf, 1987, "Recruitment of the long term unemployed", Institute of Manpower Studies, Report no. 138, University of Sussex.

Nilsson, C., 1992, "The Swedish model: labour market institutions and contracts", Working Paper 1992:4, Department of Economics, Uppsala University.

OECD, 1999, Benefit systems and work incentives, OECD: Paris.

OECD, 2000, Economic Outlook, OECD: Paris. 
Oi, W. Y. and T. L. Idson, 1999, "Firm size and wages", in Handbook of Labor Economics, volume 3A (eds. O. Ashenfelter and D. Card), Elsevier: Amsterdam.

Priks, M., 2002, "Why do cooperatives use egalitarian wage schedules", mimeo, Department of Economics, Stockholm University.

Rabin, M., 1993, "Incorporating fairness into game theory and economics", American Economic Review 83, 1281-1302.

Rebitzer, J. B. and M. D. Robinson, 1991, "Employer size and dual labor markets", Review of Economics and Statistics 73, 710-715.

Shafir, E., P. Diamond and A. Tversky, 1997, "Money illusion”, Quarterly Journal of Economics 112, 341-74.

Shapiro, C. and J. E. Stiglitz, 1984, "Equilibrium unemployment as a worker discipline device", American Economic Review 74, 433-444.

Smith, J. C., 2000, "Nominal wage rigidity in the United Kingdom", The Economic Journal 110, C176-C195.

Solow, R. M., 1990, The labor market as a social institution. Basil Blackwell, Cambridge (MA.).

Summers, L. H.,1988, "Relative wages, efficiency wages, and Keynesian unemployment", American Economic Review 78 (Papers and proceedings), 383-388.

Tobin, J., 1972, "Inflation and unemployment", American Economic Review 62, 1-18. 


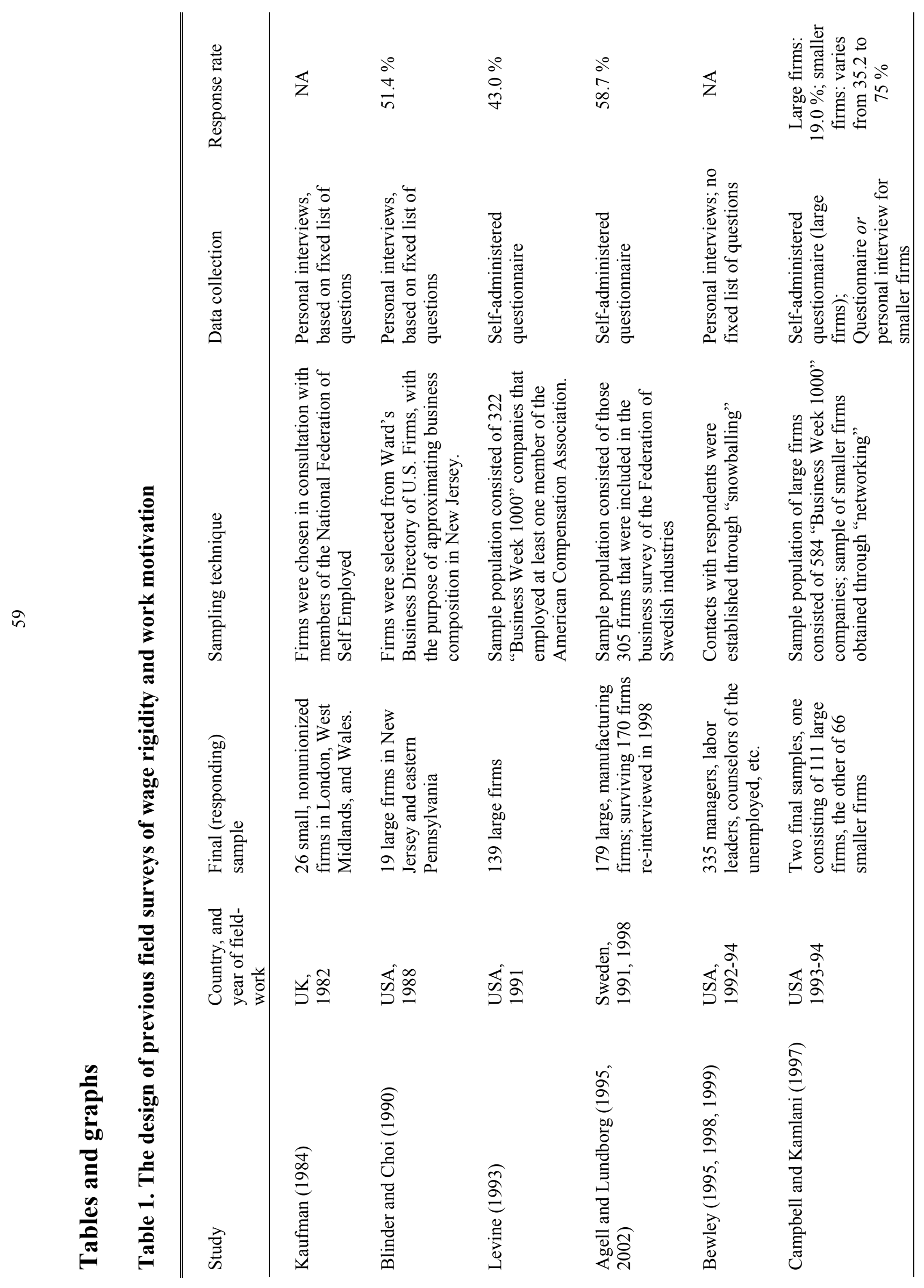









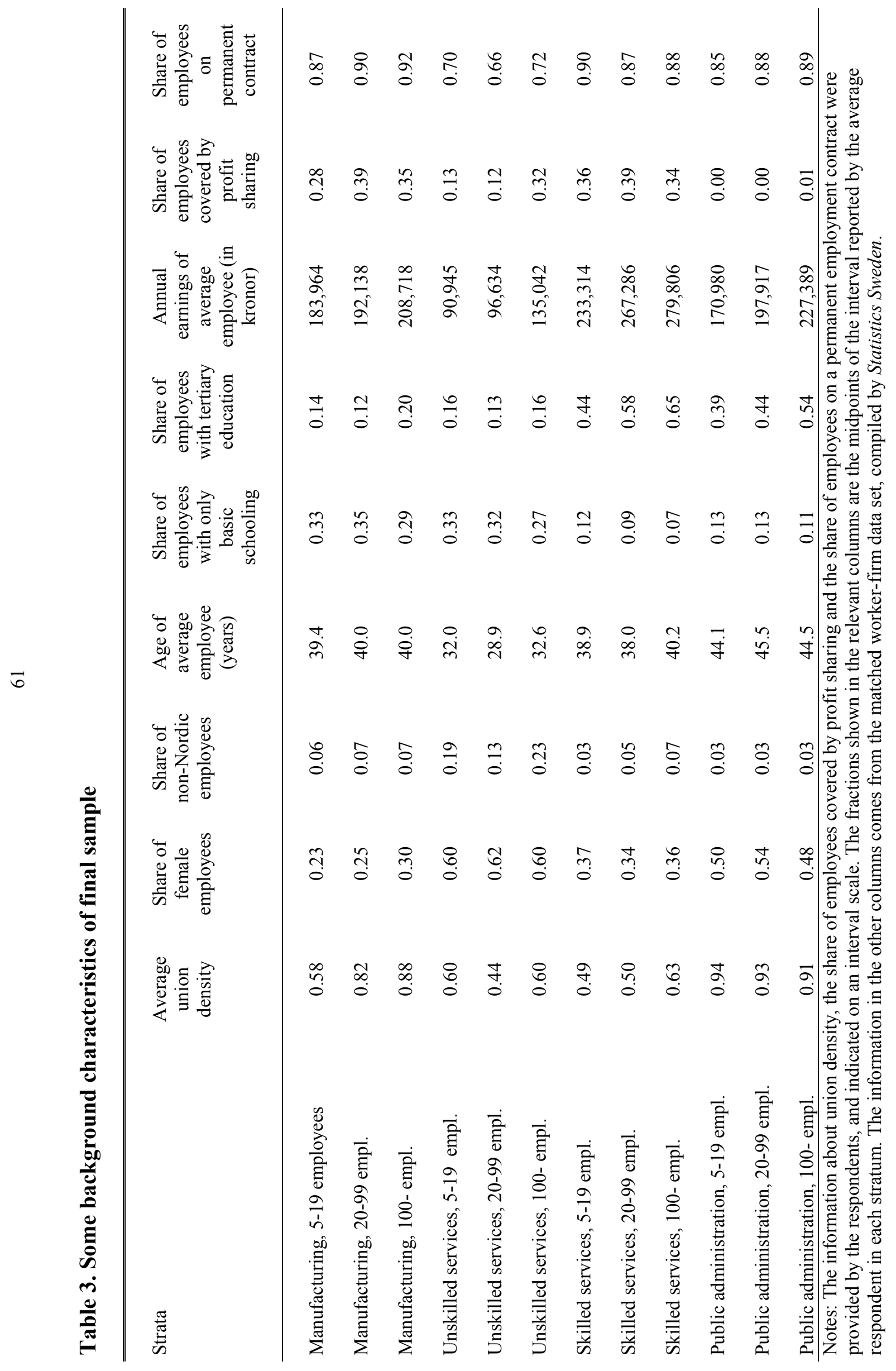


Table 4. Explanatory variables used in the logit analysis

\begin{tabular}{|c|c|c|c|c|c|}
\hline Variable & Description & Source & Mean & Std. Dev. & No. of obs \\
\hline LOGSIZE & $\operatorname{Ln}($ No. of employees of unit) & $\mathrm{BR}$ & 3.68 & 1.35 & 885 \\
\hline UNIONDENSITY & $\begin{array}{l}\text { Share of workforce that is } \\
\text { unionized }\end{array}$ & Q & 0.70 & 0.32 & 867 \\
\hline PERMCONTRACT & $\begin{array}{l}\text { Share of employees with a } \\
\text { permanent employment } \\
\text { contract }\end{array}$ & Q & 0.85 & 0.20 & 879 \\
\hline FEMALE & Share of female employees & ER & 0.41 & 0.25 & 845 \\
\hline NONNORDIC & $\begin{array}{l}\text { Share of employees of non- } \\
\text { Nordic origin }\end{array}$ & ER & 0.07 & 0.12 & 845 \\
\hline AGE & Average age of workforce & ER & 39.5 & 7.2 & 845 \\
\hline $\mathrm{AGE}^{*} \mathrm{AGE}$ & $\begin{array}{l}\text { Square of AGE divided by } \\
100\end{array}$ & & & & \\
\hline BASICSCHOOL & $\begin{array}{l}\text { Share of employees with only } \\
\text { basic schooling }\end{array}$ & ER & 0.21 & 0.18 & 845 \\
\hline UNIVERSITY & $\begin{array}{l}\text { Share of employees with } \\
\text { university education }\end{array}$ & ER & 0.33 & 0.28 & 845 \\
\hline MULTIUNIT & $\begin{array}{l}=1 \text { if unit is part of multiunit } \\
\text { enterprise }\end{array}$ & $\mathrm{BR}$ & 0.58 & 0.49 & 885 \\
\hline \multicolumn{6}{|l|}{$\underline{\text { INDUSTRY }}$} \\
\hline UNSKILLSER & $=1$ if skilled service unit & $\mathrm{BR}$ & 0.16 & 0.37 & 885 \\
\hline SKILLSER & $=1$ if unskilled service unit & BR & 0.25 & 0.43 & 885 \\
\hline PUBLIC & $\begin{array}{l}=1 \text { if public unit } \\
\text { (Manufacturing units used as } \\
\text { reference) }\end{array}$ & $\mathrm{BR}$ & 0.29 & 0.45 & 885 \\
\hline \multicolumn{6}{|l|}{$\underline{\text { POPULATION }}$} \\
\hline LOWPOP & $\begin{array}{l}=1 \text { if unit is in area with low } \\
\text { population density (Statistics } \\
\text { Sweden regional codes H5, } \\
\text { H6) }\end{array}$ & $\mathrm{BR}$ & 0.11 & 0.32 & 885 \\
\hline MEDIUMPOP & $\begin{array}{l}=1 \text { if unit is in area with } \\
\text { average population density } \\
\text { (Statistics Sweden regional } \\
\text { codes H3, H4) } \\
\text { (Units located in areas with } \\
\text { high population density used } \\
\text { as reference) }\end{array}$ & $\mathrm{BR}$ & 0.49 & 0.50 & 885 \\
\hline
\end{tabular}

Notes: In the third column, BR stands for the Business Register of Statistics Sweden, Q for the questionnaire, and ER for the Employment Register of Statistics Sweden. 
Table 5. The validity of our background data: OLS earnings-equations

Explanatory variables

Dependent variable: LOGEARNING

\begin{tabular}{ccc}
\hline $\begin{array}{c}\text { No industry } \\
\text { dummies }\end{array}$ & $\begin{array}{c}\text { Industry dummies } \\
\text { according to Table } 4\end{array}$ & $\begin{array}{c}\text { Industry dummies } \\
\text { according to two- } \\
\text { digit SIC code }^{35}\end{array}$
\end{tabular}

\begin{tabular}{|c|c|c|c|}
\hline LOGSIZE & $\begin{array}{l}.043 * * \\
(.009)\end{array}$ & $\begin{array}{l}.038 * * \\
(.009)\end{array}$ & $\begin{array}{l}.043^{* *} \\
(.009)\end{array}$ \\
\hline UNIONDENSITY & $-.217 * *$ & $-.159 * *$ & $-.127 * *$ \\
\hline & $(.042)$ & $(.043)$ & $(.043)$ \\
\hline PERMCONTRACT & $.359 * *$ & $.325 * *$ & $.311 * *$ \\
\hline FEMALE & $\begin{array}{c}-.463 * * \\
(.045)\end{array}$ & $\begin{array}{c}-.345 * * \\
(.050)\end{array}$ & $\begin{array}{c}-.401 * * \\
(.054)\end{array}$ \\
\hline NONNORDIC & $\begin{array}{c}-.385^{* *} \\
(.101)\end{array}$ & $\begin{array}{c}-.334 * * \\
(.104)\end{array}$ & $\begin{array}{c}-.334 * * \\
(.101)\end{array}$ \\
\hline AGE & $\begin{array}{l}.185 * * \\
(.013)\end{array}$ & $\begin{array}{l}.163 * * \\
(.013)\end{array}$ & $\begin{array}{l}.160 * * \\
(.013)\end{array}$ \\
\hline AGE*AGE & $\begin{array}{c}-.202 * * \\
(.017)\end{array}$ & $\begin{array}{c}-.174 * * \\
(.017)\end{array}$ & $\begin{array}{c}-.170 * * \\
(.017)\end{array}$ \\
\hline BASICSCHOOL & $\begin{array}{c}-.505^{* *} \\
(.083)\end{array}$ & $\begin{array}{c}-.600 * * \\
(.084)\end{array}$ & $\begin{array}{c}-.600 * * \\
(.083)\end{array}$ \\
\hline UNIVERSITY & $\begin{array}{l}.398 * * \\
(.057)\end{array}$ & $\begin{array}{l}.430 * * \\
(.061)\end{array}$ & $\begin{array}{l}.447 * * \\
(.059)\end{array}$ \\
\hline $\operatorname{Adj} R^{2}$ & .64 & .65 & .67 \\
\hline No. of observations & 824 & 824 & 824 \\
\hline
\end{tabular}

Notes: The dependent variable (the log of average annual earnings) is calculated via the tax registers, included in the Employment register of Statistics Sweden. All regressions include a constant, MULTIUNIT, LOWPOP and MEDIUMPOP. Standard errors are shown in parentheses. $*$ denotes significance at five percent level, ** denotes significance at one percent level.

\footnotetext{
35 Our units were classified into nine categories based on the SIC-codes: K72; K73; part of K74; D20-21 and 23-27; D28-35; D15-19, 22 and 36-37; H55; L75111-75212, 75231, 75232 and 75300; L75221-75226 and 75233-75250.
} 
Table 6. Frequency of nominal wage cuts (defined as cut in regular hourly or monthly wages, or piece rates) during the "crisis years" of the 1990s

\begin{tabular}{lcccc}
\hline \hline Sector & $\begin{array}{c}\text { No. of units } \\
\text { reporting some } \\
\text { experience with } \\
\text { wage cuts }\end{array}$ & $\begin{array}{c}\text { Incidence of wage } \\
\text { cuts in sector (in } \\
\text { percent) }\end{array}$ & $\begin{array}{c}\text { No. of units } \\
\text { reporting } \\
\text { experience with } \\
\text { comprehensive } \\
\text { wage cut }\end{array}$ & $\begin{array}{c}\text { Incidence of } \\
\text { comprehensive } \\
\text { wage cuts in sector } \\
\text { (in percent) }\end{array}$ \\
\hline Manufacturing & 9 & 3.4 & 2 & 0.8 \\
Unskilled services & 6 & 4.3 & 0 & 0.0 \\
Skilled services & 12 & 5.5 & 7 & 3.2 \\
Public & 1 & 0.4 & 0 & 0.0 \\
administration & 28 & 3.2 & 9 & 1.0 \\
\hline Total & & & & \\
\hline
\end{tabular}

Notes: The figures shown in the third and fifth columns are the percentage of all firms in the sector that have experienced a wage cut. We define a comprehensive wage cut as a wage cut that covers at least 50 percent of the employees at a given unit. 
Table 7. Incidence of underbidding, and of employers' rejection of underbidders

\begin{tabular}{lcccc}
\hline \hline Sector & $\begin{array}{c}\text { No. of units } \\
\text { reporting that they } \\
\text { have been } \\
\text { contacted by } \\
\text { underbidders }\end{array}$ & $\begin{array}{c}\text { Incidence of } \\
\text { underbidding in } \\
\text { sector (in percent) }\end{array}$ & $\begin{array}{c}\text { No. of units } \\
\text { reporting that they } \\
\text { have always } \\
\text { refused the offer }\end{array}$ & $\begin{array}{c}\text { Rejection rate } \\
\text { (in percent) }\end{array}$ \\
\hline Manufacturing & 34 & 12.6 & 32 & 97.0 \\
Unskilled services & 27 & 19.4 & 24 & 82.3 \\
Skilled services & 29 & 13.4 & 23 & 82.1 \\
Public & 11.4 & 13.5 & 103 & 89.6 \\
\hline administration & 119 & 13.5 & 24 \\
\hline
\end{tabular}

Notes: Four of the 119 firms that replied that they had been contacted by underbidders did not answer our question on whether they had rejected the offer. The rejection rates shown in the last column applies for the 115 firms that responded to this question. 
Table 8. Most important reasons to reject underbidders

Cited reason

Percentage of respondents that rank the reason as most important in explaining why they reject underbidders

\begin{tabular}{lccc}
\hline Manufacturing & $\begin{array}{c}\text { Unskilled } \\
\text { services }\end{array}$ & Skilled services & $\begin{array}{c}\text { Public } \\
\text { administration }\end{array}$ \\
\hline
\end{tabular}

Violates firm's personnel

41.7

32.6

37.2

29.5

policy; creates internal conflicts

$\begin{array}{lcccc}\text { No vacancies } & 37.0 & 29.9 & 42.0 & 28.5 \\ \begin{array}{l}\text { Violates collective } \\ \text { bargaining agreement; } \\ \text { unions resist underbidders }\end{array} & 18.2 & 33.0 & 16.4 & 42.1 \\ \begin{array}{l}\text { Underbidders have } \\ \text { inferior skills }\end{array} & 3.1 & 4.5 & 4.5 & 0.0\end{array}$

Notes: The percentages shown in the four columns are based on the replies of 33, 22, 26 and 25 units, respectively. 
Table 9. Logit analysis of determinants of effort and motivation

\begin{tabular}{|c|c|c|c|c|}
\hline \multirow{2}{*}{$\begin{array}{l}\text { Explanatory } \\
\text { variables }\end{array}$} & \multicolumn{4}{|c|}{ Dependent variable } \\
\hline & $\begin{array}{l}\text { Can evaluate } \\
\text { individual } \\
\text { performance } \\
(1=\text { yes, } 0=\text { no })\end{array}$ & $\begin{array}{l}\text { Can evaluate team } \\
\text { performance } \\
(1=\text { yes, } 0=\text { no })\end{array}$ & $\begin{array}{c}\text { Higher external } \\
\text { wages lowers } \\
\text { effort } \\
(1=\text { yes, } 0=\text { no })\end{array}$ & $\begin{array}{c}\text { Employees who } \\
\text { feel underpaid } \\
\text { reduce effort } \\
(1=\text { yes, } 0=\text { no })\end{array}$ \\
\hline LOGSIZE & $\begin{array}{c}-.180 * * \\
(.061)\end{array}$ & $\begin{array}{c}-.195 * * \\
(.065)\end{array}$ & $\begin{array}{l}.226 * * \\
(.065)\end{array}$ & $\begin{array}{l}176^{* *} \\
(.061)\end{array}$ \\
\hline FEMALE & $\begin{array}{l}-.070 \\
(.340)\end{array}$ & $\begin{array}{l}.896^{*} \\
(.374)\end{array}$ & $\begin{array}{l}-.377 \\
(.356)\end{array}$ & $\begin{array}{c}-.965 * * \\
(.345)\end{array}$ \\
\hline PUBLIC & $\begin{array}{l}-.566^{*} \\
(.278)\end{array}$ & $\begin{array}{l}-.707 * \\
(.296)\end{array}$ & $\begin{array}{l}.283 \\
(.296)\end{array}$ & $\begin{array}{l}.163 \\
(.277)\end{array}$ \\
\hline Industry dummies & Table 4 & Table 4 & Table 4 & Table 4 \\
\hline Other controls & Table 4 & Table 4 & Table 4 & Table 4 \\
\hline Pseudo R-squared & .039 & .061 & .043 & .038 \\
\hline No. of obs. & 823 & 752 & 822 & 815 \\
\hline $\begin{array}{l}\text { No. of dependent } \\
\text { variable }=1\end{array}$ & 424 & 389 & 543 & 395 \\
\hline
\end{tabular}




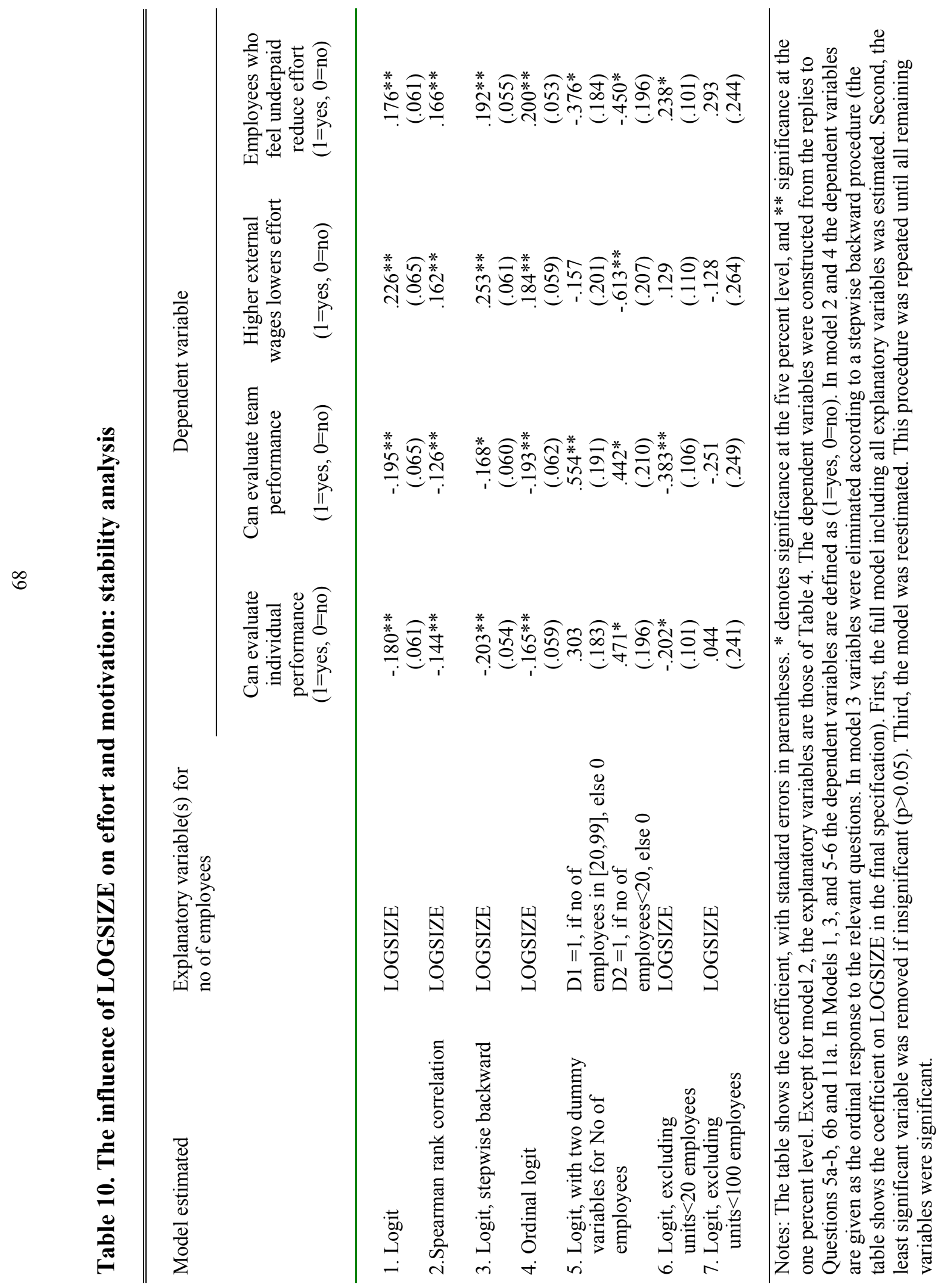




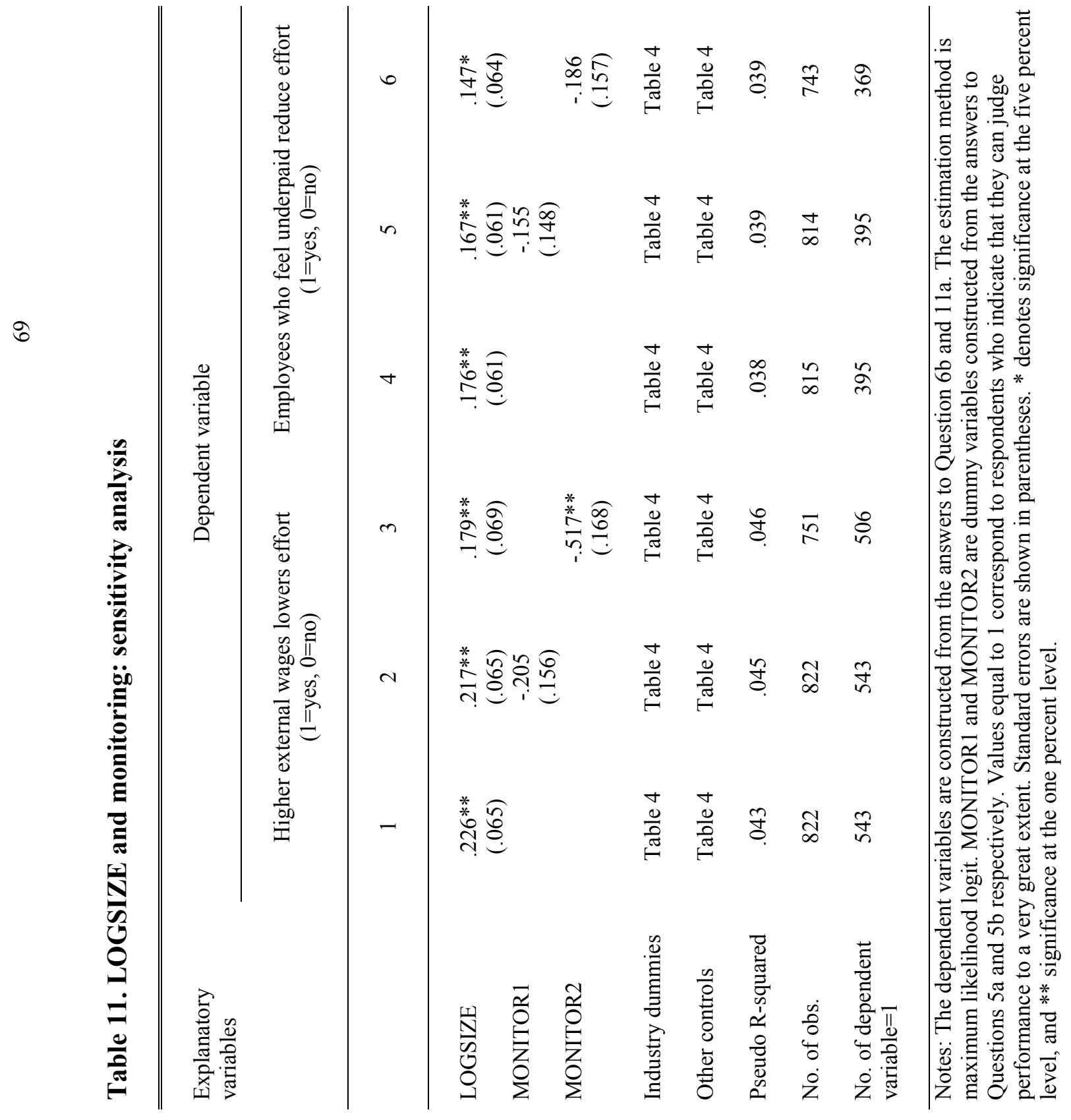


Table 12. Logit analysis of determinants of risk of voluntary turnover

Explanatory

variables
Dependent variable

$\begin{array}{cc}\begin{array}{c}\text { Employees who feel } \\ \text { underpaid seek other } \\ \text { jobs }\end{array} & \begin{array}{c}\text { Employees who feel } \\ \text { underpaid seek other } \\ \text { jobs }\end{array} \\ \text { (1=yes, } 0=\text { no) } & \text { (ordered logit model) }\end{array}$

\begin{tabular}{lccc}
\hline UNIONDENSITY & $-.741^{*}$ & $-.775^{*}$ & $-.925^{* *}$ \\
PERMCONTRACT & $(.319)$ & $(.323)$ & $(.273)$ \\
& -.828 & -.709 & $-.730^{*}$ \\
UNIVERSITY & $(.439)$ & $(.439)$ & $(.370)$ \\
LOWPOP & $1.255^{* *}$ & $1.352^{* *}$ & $\left(.373^{* *}\right.$ \\
& $(.438)$ & $(.450)$ & $-.516^{*}$ \\
Industry dummies & $-.598^{*}$ & $-.571^{*}$ & $(.244)$ \\
Other controls & $(.276)$ & $(.280)$ & Table 4 \\
Pseudo R-squared & Table 4 & Two-digit & Table 4 \\
No. of obs. & Table 4 & Table 4 & .048 \\
No. of dependent & .081 & .093 & 821 \\
variable=1 & 821 & 821 & -- \\
\end{tabular}

Notes: The dependent variable was constructed from the answers to Questions 11b. In columns 1-2 the estimation method is maximum likelihood logit. In column 3 the estimation method is maximum likelihood ordered logit (five response categories). Standard errors are shown in parentheses. * denotes significance at the five percent level, and ** significance at the one percent level. 
Table 13. Logit analysis of link between effort and unemployment benefits

Explanatory

variables
Dependent variable:

Higher unemployment benefits lower effort

$(1=$ yes, $0=$ no)

\begin{tabular}{|c|c|c|c|c|}
\hline & 1 & 2 & 3 & 4 \\
\hline PERMCONTRACT & $\begin{array}{c}-1.550 * * \\
(.468)\end{array}$ & $\begin{array}{c}-1.534 * * \\
(.472)\end{array}$ & & $\begin{array}{c}-1.463 * * \\
(.485)\end{array}$ \\
\hline BASICSCHOOL & $\begin{array}{c}1.947^{* *} \\
(.743)\end{array}$ & $\begin{array}{l}1.871^{*} \\
(.765)\end{array}$ & & $\begin{array}{l}1.745^{*} \\
(.782)\end{array}$ \\
\hline LOGEARNING & & & $\begin{array}{l}-.955^{* *} \\
(.183)\end{array}$ & $\begin{array}{l}-.225 \\
(.309)\end{array}$ \\
\hline Industry dummies & No & Table 4 & No & Table 4 \\
\hline Other controls & Table 4 & Table 4 & No & Table 4 \\
\hline Pseudo R-squared & .101 & .103 & .043 & .103 \\
\hline No. of obs. & 818 & 818 & 836 & 818 \\
\hline $\begin{array}{l}\text { No. of dependent } \\
\text { variable }=1\end{array}$ & 113 & 113 & 118 & 113 \\
\hline
\end{tabular}

Notes: The variable LOGEARNING is the log of annual earnings, also used as the dependent variable in Table 5. The dependent variable was constructed from the answers to Question 6c. In all columns the estimation method is maximum likelihood logit. Standard errors are shown in parentheses. ${ }^{*}$ denotes significance at the five percent level, and ${ }^{* *}$ significance at the one percent level. 
Table 14. Logit analysis of determinants of rent-sharing

Explanatory

variables
Dependent variable

\begin{tabular}{|c|c|c|c|}
\hline $\begin{array}{l}\text { Profits/ability to } \\
\text { pay matters } \\
(1=\text { yes, } 0=\text { no })\end{array}$ & $\begin{array}{l}\text { Profits/ability to } \\
\text { pay matters } \\
(1=\text { yes, } 0=\text { no })\end{array}$ & $\begin{array}{l}\text { Profits/ability to } \\
\text { pay matters } \\
\text { (ordered logit) }\end{array}$ & $\begin{array}{l}\text { Profits/ability to } \\
\text { pay matters } \\
\text { (ordered logit) }\end{array}$ \\
\hline
\end{tabular}

\begin{tabular}{|c|c|c|c|c|}
\hline \multirow[t]{2}{*}{ LOGSIZE } & $.304 * *$ & $.339 * *$ & $.339 * *$ & $.379 * *$ \\
\hline & $(.068)$ & $(.071)$ & $(.057)$ & $(.058)$ \\
\hline \multirow[t]{2}{*}{ UNIONDENSITY } & .396 & .459 & .349 & .414 \\
\hline & $(.326)$ & $(.335)$ & $(.270)$ & $(.275)$ \\
\hline \multirow[t]{2}{*}{ PERMCONTRACT } & .760 & .673 & $.912 *$ & $.932 *$ \\
\hline & $(.497)$ & $(.501)$ & $(.377)$ & $(.383)$ \\
\hline \multirow[t]{2}{*}{ FEMALE } & $-1.155^{* *}$ & $-1.407 * *$ & $-1.283 * *$ & $-1.651 * *$ \\
\hline & $(.404)$ & $(.460)$ & $(.315)$ & $(.357)$ \\
\hline Industry dummies & Table 4 & Two-digit & Table 4 & Two-digit \\
\hline Other controls & Table 4 & Table 4 & Table 4 & Table 4 \\
\hline Pseudo R-squared & .127 & .136 & .087 & .097 \\
\hline No. of obs. & 817 & 817 & 817 & 817 \\
\hline $\begin{array}{l}\text { No. of dependent } \\
\text { variable=1 }\end{array}$ & 281 & 281 & -- & -- \\
\hline
\end{tabular}

Notes: The dependent variables were constructed from the answers to Questions 10c. In columns 1-2 the estimation method is maximum likelihood logit. In columns 3-4 the estimation method is maximum likelihood ordered logit (five response categories). Standard errors are shown in parentheses. * denotes significance at the five percent level, and ** significance at the one percent level. 


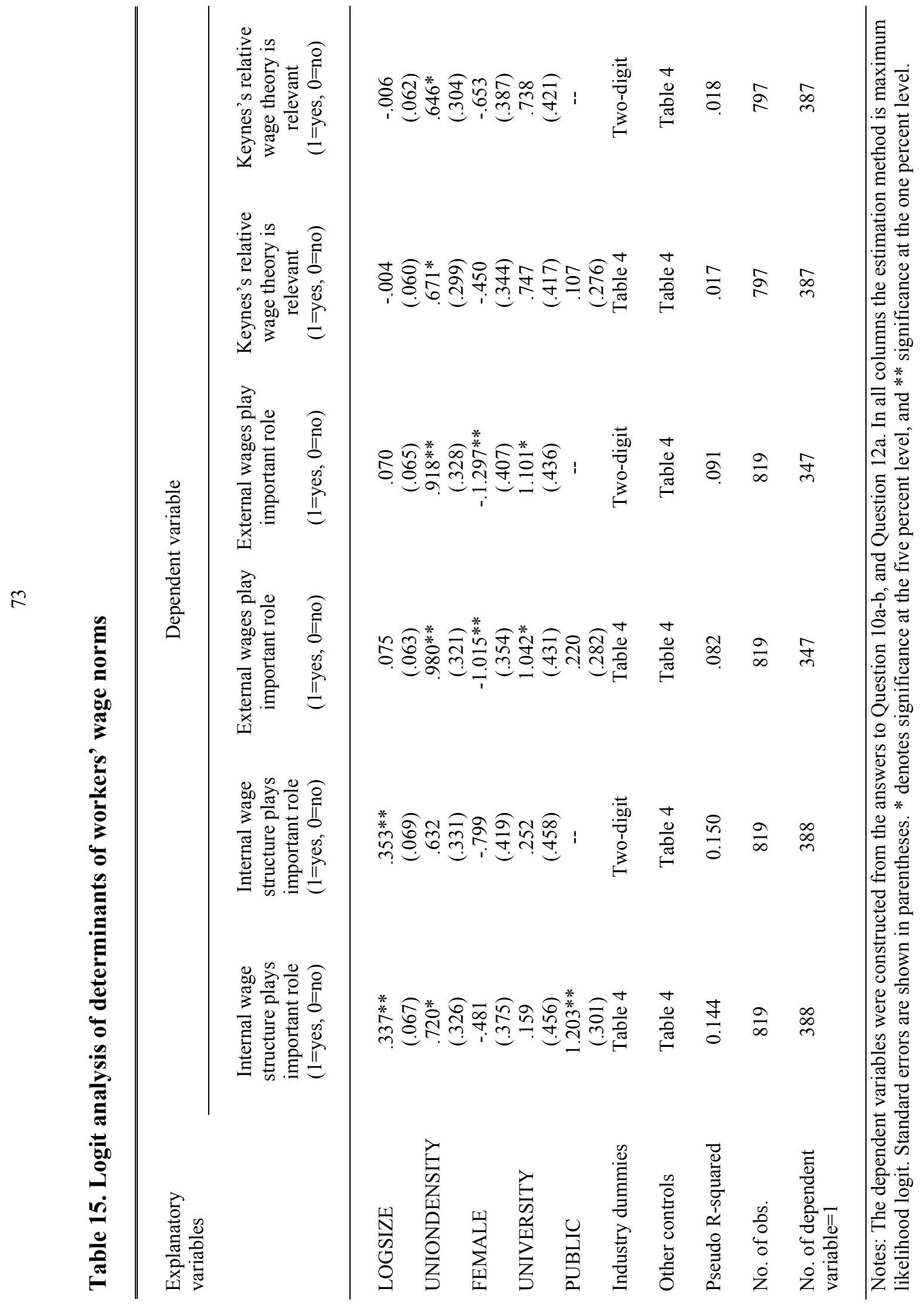




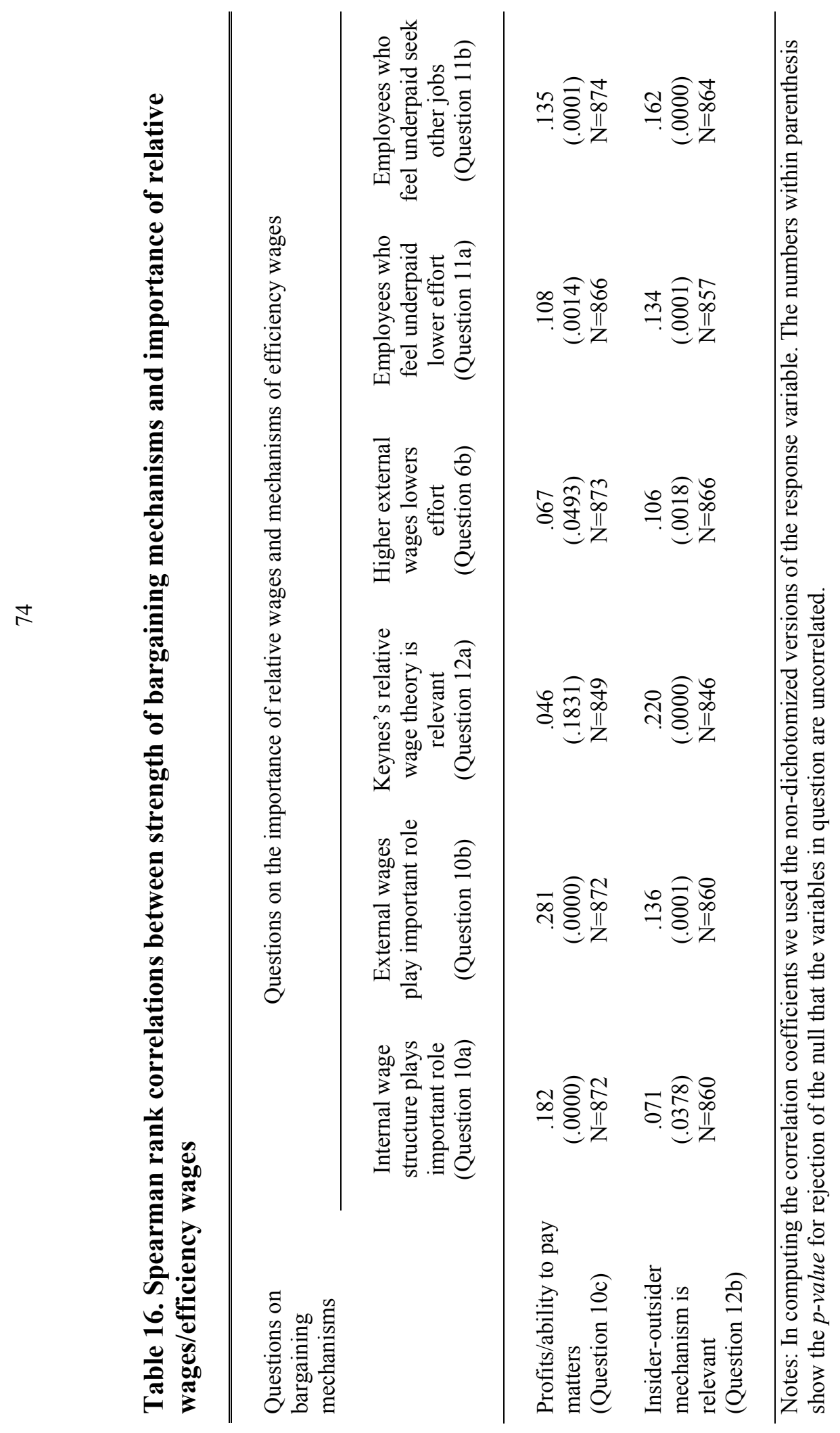


Table 17. Logit analysis of attitudes towards job protection

Explanatory variables
Dependent variable:

\begin{tabular}{|c|c|c|}
\hline $\begin{array}{l}\text { Job protection } \\
\text { reduces hirings? } \\
(1=\text { yes, } 0=\text { no })\end{array}$ & $\begin{array}{l}\text { Job protection } \\
\text { reduces hirings? } \\
(1=\text { yes, } 0=\text { no })\end{array}$ & $\begin{array}{l}\text { Job protection } \\
\text { reduces hirings? } \\
\text { (ordered logit } \\
\text { model) }\end{array}$ \\
\hline $\begin{array}{c}-.183^{* *} \\
(.066) \\
-1.973 * \\
(.787) \\
-1.505^{* *} \\
(.307)\end{array}$ & $\begin{array}{c}-.143^{*} \\
(.070) \\
-2.022^{*} \\
(.796) \\
--\end{array}$ & $\begin{array}{c}-.161 * * \\
(.054) \\
-1.451^{*} \\
(.637) \\
-1.540^{* *} \\
(.253)\end{array}$ \\
\hline Table 4 & Two-digit & Table 4 \\
\hline Table 4 & Table 4 & Table 4 \\
\hline .089 & .097 & .057 \\
\hline 812 & 812 & 812 \\
\hline 315 & 315 & -- \\
\hline
\end{tabular}

Notes: The dependent variable is constructed from the answers to Question 4b. In columns 1-2 the estimation method is maximum likelihood logit. In column 3 the estimation method is maximum likelihood ordered logit (four response categories). Standard errors are shown in parentheses. ${ }^{*}$ denotes significance at the five percent level, and ** significance at the one percent level. 
Table 18. Spearman rank correlations between perceived strictness of job protection and perceived stigma from long-term unemployment

Questions on stigma

Questions on the importance of job protection from long-term unemployment or training

\begin{tabular}{|c|c|c|}
\hline $\begin{array}{l}\text { Job protection } \\
\text { leads to more } \\
\text { careful screening? } \\
\text { (Question 4a) }\end{array}$ & $\begin{array}{l}\text { Job protection } \\
\text { reduces hirings? } \\
\text { (Question 4b) }\end{array}$ & $\begin{array}{c}\text { Job protection } \\
\text { boosts temporary } \\
\text { contracts } \\
\text { (Question 4c) }\end{array}$ \\
\hline
\end{tabular}

\begin{tabular}{lccc}
\hline Stigma from & .125 & .100 & .182 \\
unemployment? & $(.0003)$ & $(.0033)$ & $(.0000)$ \\
(Question 14a) & $\mathrm{N}=858$ & $\mathrm{~N}=857$ & $\mathrm{~N}=856$ \\
& & & \\
Stigma from & .120 & .118 & .194 \\
unempl./training? & $(.0005)$ & $(.0006)$ & $(.0000)$ \\
(Question 14b) & $\mathrm{N}=856$ & $\mathrm{~N}=855$ & $\mathrm{~N}=854$
\end{tabular}

Notes: In computing the correlation coefficients we used the non-dichotomized versions of the response variables, see main text for further details. The numbers within parenthesis show the $p$-value for rejection of the null that the variables in question are uncorrelated. 
Table 19. Importance of different motivational tools in different sectors

Motivational tool

Percentage of respondents that use the motivational tool to a "great" or "fairly great" extent

Manufacturing. $\begin{gathered}\text { Unskilled } \\ \text { services }\end{gathered}$ Skilled services $\begin{gathered}\text { Public } \\ \text { administration }\end{gathered}$

\begin{tabular}{|c|c|c|c|c|}
\hline $\begin{array}{l}\text { Supervision and } \\
\text { monitoring }\end{array}$ & 13.0 & 27.9 & 18.4 & 7.0 \\
\hline Career ladders & 17.1 & 34.3 & 40.7 & 13.7 \\
\hline Performance related pay & 15.0 & 10.0 & 16.7 & 5.9 \\
\hline $\begin{array}{l}\text { Good-management } \\
\text { worker relations }\end{array}$ & 58.2 & 69.8 & 68.1 & 63.1 \\
\hline
\end{tabular}

Notes: The numbers are calculated from the replies to Questions 9a-d. 
Table 20. Logit analysis of incidence of motivational tools

Explanatory

variables
Dependent variable

\begin{tabular}{|c|c|c|c|}
\hline $\begin{array}{l}\text { Supervision and } \\
\text { monitoring used } \\
\text { extensively } \\
(1=\text { yes, } 0=\text { no })\end{array}$ & $\begin{array}{l}\text { Career tracks used } \\
\text { extensively } \\
\quad(1=\text { yes, } 0=\text { no })\end{array}$ & $\begin{array}{l}\text { Performance } \\
\text { related pay used } \\
\text { extensively } \\
(1=\text { yes, } 0=\text { no })\end{array}$ & $\begin{array}{l}\text { Measures to } \\
\text { promote good } \\
\text { management- } \\
\text { worker relations } \\
\text { used extensively } \\
(1=\text { yes, } 0=\text { no })\end{array}$ \\
\hline $\begin{array}{c}-1.570 * * \\
(.420) \\
-.698 \\
(.578) \\
.040 \\
(.060) \\
.431 \\
(.276) \\
-.373 \\
(.340) \\
-.137 \\
(.179)\end{array}$ & $\begin{array}{c}.143 \\
(.449) \\
-1.041 \\
(.620) \\
.259^{* *} \\
(.067) \\
-1.016^{* *} \\
(.306) \\
-1.059^{* *} \\
(.363) \\
.945^{* *} \\
(.209)\end{array}$ & $\begin{array}{c}-.391 \\
(.430) \\
-1.510^{*} \\
(.623) \\
.180^{* *} \\
(.062) \\
-1.196^{* *} \\
(.288) \\
-.186 \\
(.352) \\
.291 \\
(.182)\end{array}$ & $\begin{array}{c}-.419 \\
(.435) \\
-1.706^{* *} \\
(.605) \\
.000 \\
(.062) \\
-.209 \\
(.287) \\
.398 \\
(.354) \\
.491 * * \\
(.187)\end{array}$ \\
\hline Table 4 & Table 4 & Table 4 & Table 4 \\
\hline Table 4 & Table 4 & Table 4 & Table 4 \\
\hline .038 & .108 & .074 & .032 \\
\hline 823 & 821 & 820 & 820 \\
\hline 431 & 541 & 393 & 525 \\
\hline
\end{tabular}

Notes: The dependent variable is constructed from the answers to Questions 9a-d. In all columns the estimation method is maximum likelihood logit. Standard errors are shown in parentheses. * denotes significance at the five percent level, and ** significance at the one percent level. 
Table 21. The influence of LOGSIZE on attitudes towards competition/large wage differentials: ordered logit analysis

Model estimated

Other explanatory variables except

Dependent variable

LOGSIZE

Is competition good for work motivation?
Are wage differentials good

for work motivation?
1. Univariate Spearman correlation

2. Ordered logit

3. Ordered logit, stepwise backward

4. Ordered logit
Two-digit industrydummies, other controls as in Table 4
See Table 4

096

See Table 4

$--$

.103

(.057)

Notes: The dependent variables were constructed from the replies to Questions 7 and 8. In coding the replies to these questions, we used the following categories: $1=$ only negative, $\ldots, 5=$ only positive. In rows $2-4$ the estimation method is maximum likelihood ordered logit. The table shows parameter estimates for the coefficient on LOGSIZE, with standard errors in parentheses. $*$ denotes significance at the five percent level, and $* *$ significance at the one percent level. In model 3 all variables not significant at the five percent level were eliminated according to a stepwise procedure (-- means that LOGSIZE did not survive this procedure). 


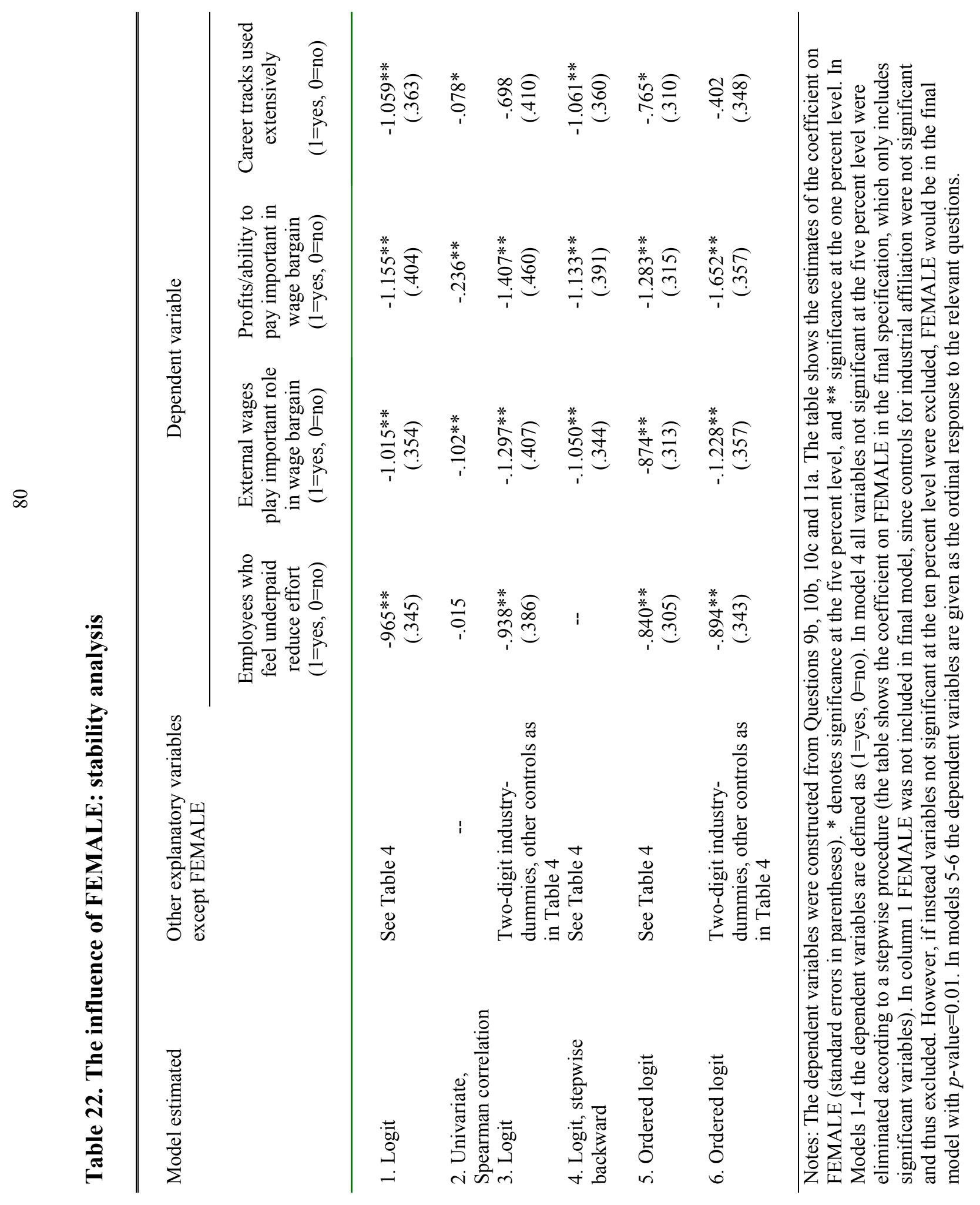




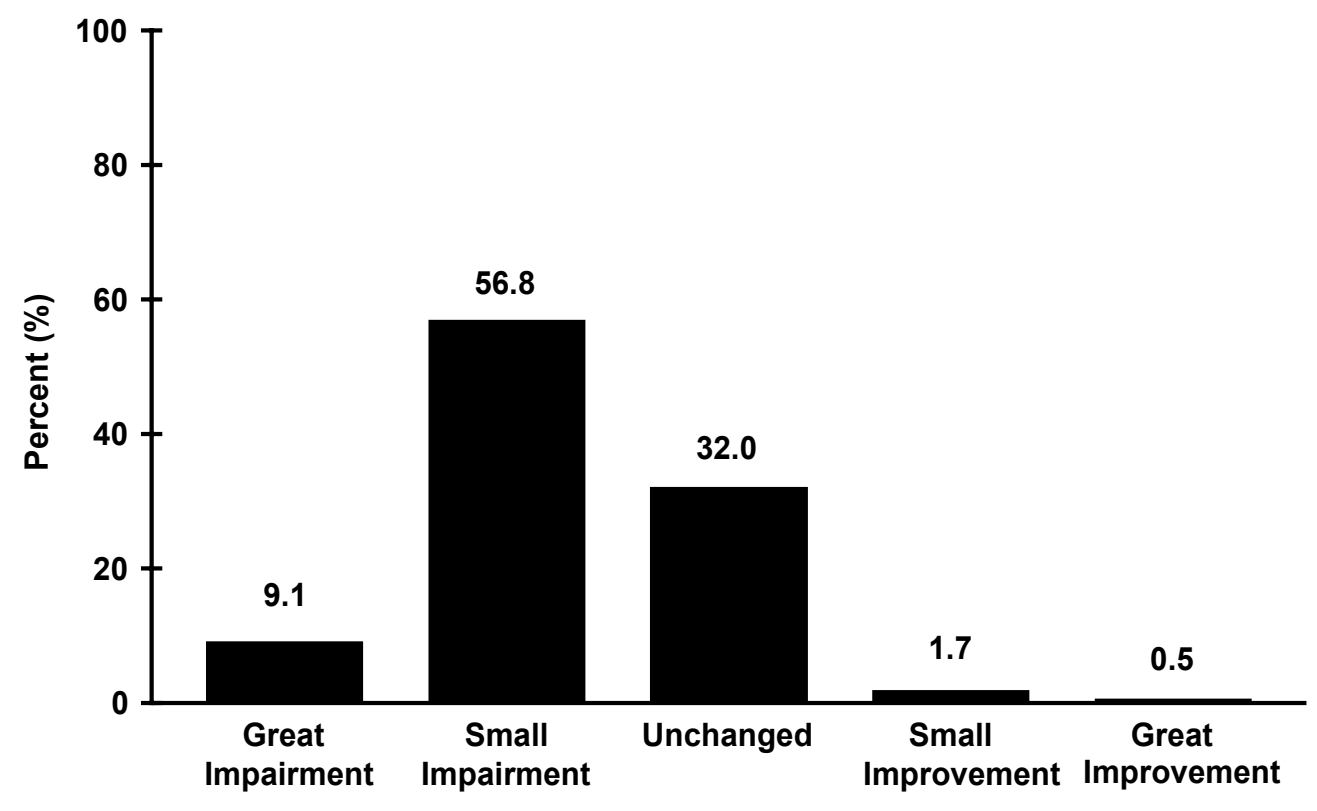

Fig. 1. "How do you think that the work effort of your employees would be affected if wages/salaries increased in comparable firms or organizations, but stayed the same at your unit?" (882 respondents) 


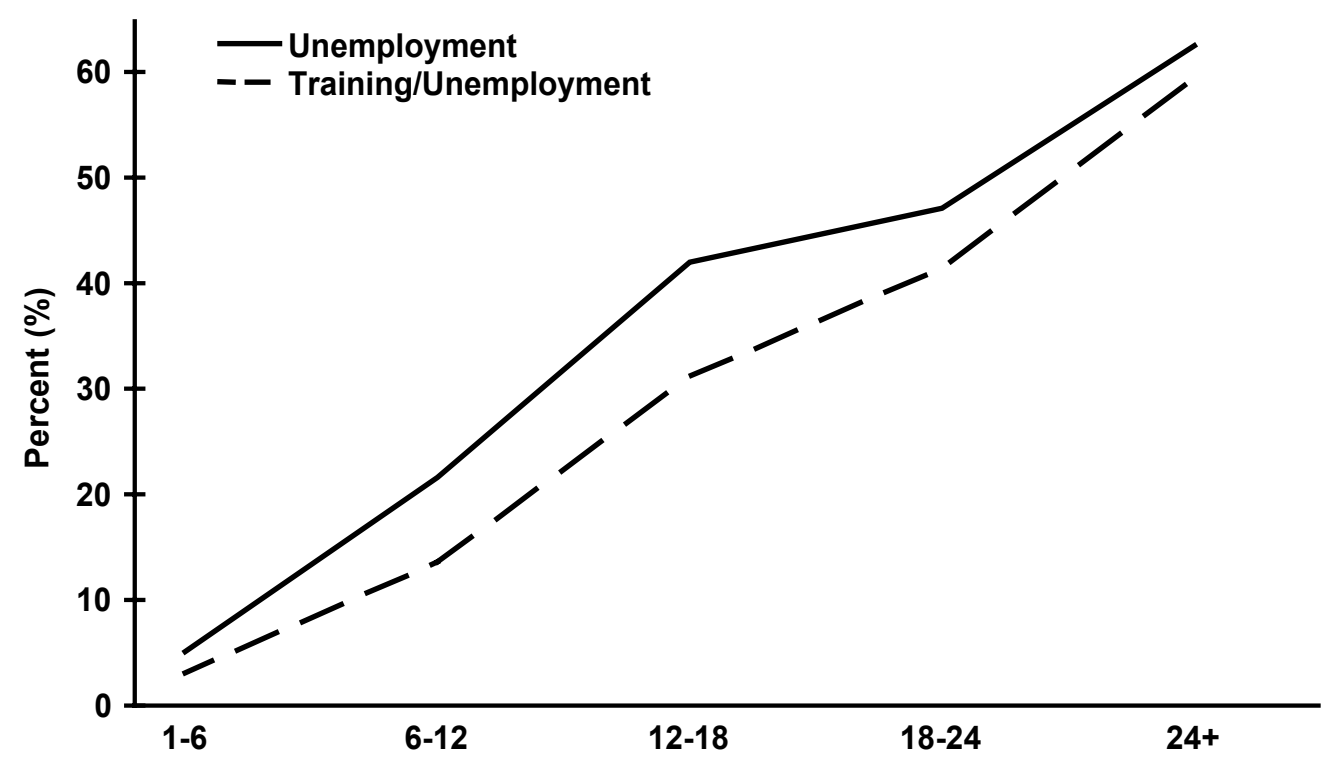

Fig. 2. "How long spell (in months) of unemployment, or training/unemployment, is required before you consider a job applicant as less suitable?" (866 respondents) 


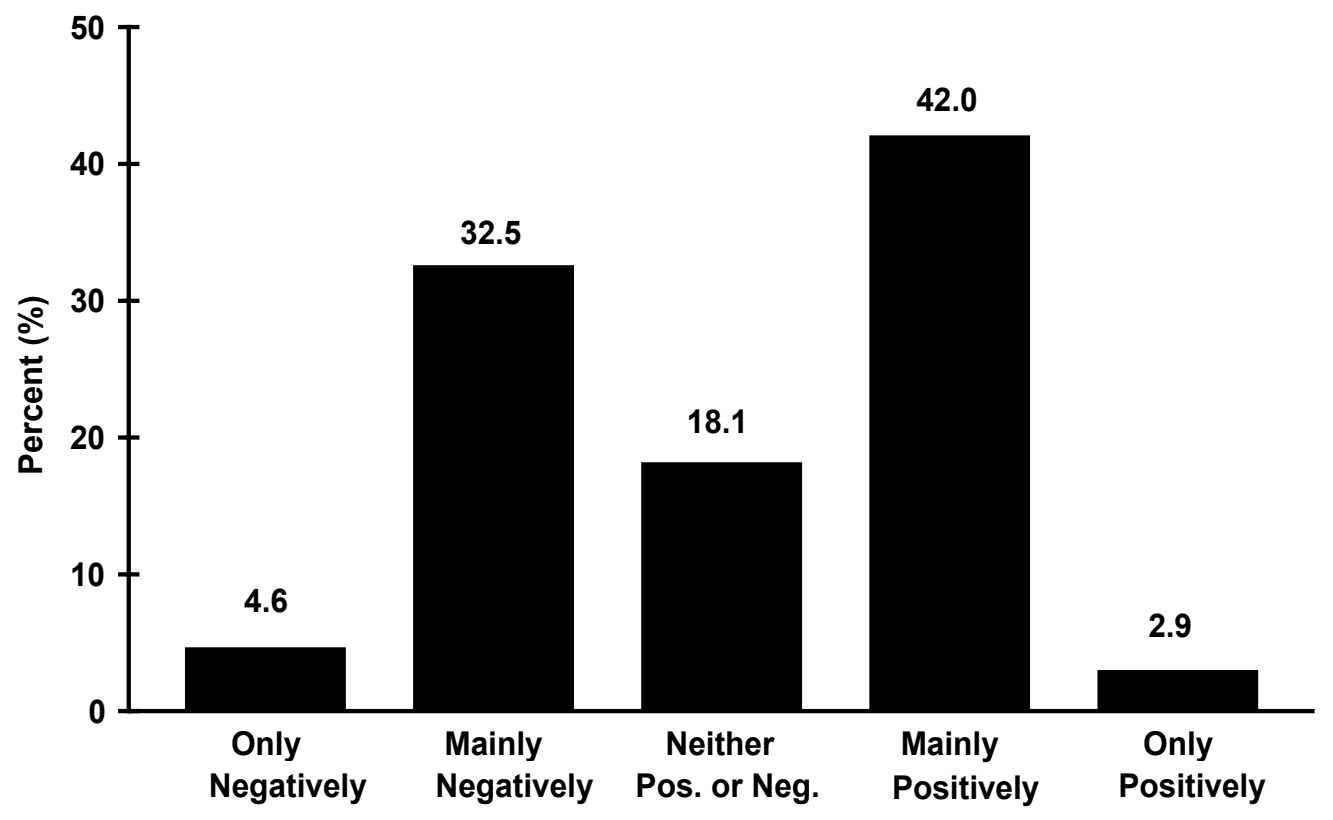

Fig. 3. "In your opinion, how does (or would) keen competition between employees affect work motivation at your workplace?" (875 respondents) 